\title{
Sri Lanka: Selected Issues
}

This Selected Issues paper for Sri Lanka was prepared by a staff team of the International Monetary Fund as background documentation for the periodic consultation with the member country. It is based on the information available at the time it was completed on October 6, 2006. The views expressed in this document are those of the staff team and do not necessarily reflect the views of the government of Sri Lanka or the Executive Board of the IMF.

The policy of publication of staff reports and other documents by the IMF allows for the deletion of market-sensitive information.

To assist the IMF in evaluating the publication policy, reader comments are invited and may be sent by e-mail to publicationpolicy@imf.org.

Copies of this report are available to the public from

International Monetary Fund • Publication Services

700 19th Street, N.W. • Washington, D.C. 20431

Telephone: (202) 6237430 • Telefax: (202) 6237201

E-mail: publications@imf.org • Internet: http://www.imf.org

Price: $\$ 18.00$ a copy

\section{International Monetary Fund Washington, D.C.}



INTERNATIONAL MONETARY FUND

SRI LANKA

Selected Issues

Prepared by Erik Lueth, Marta Ruiz-Arranz (both APD), David Coady, and David Newhouse (both FAD)

Approved by the Asia and Pacific Department

October 6, 2006

Contents

Overview

I. Macroeconomic Challenges of High Oil Prices in the South Asian Region

II. The Fiscal and Distributional Impacts of Fuel Subsidy Reform and Alternative Mitigating Measures

III Are Workers' Remittances a Hedge Against Shocks? The Case of Sri Lanka. 


\section{OVERVIEW}

\section{Over the past two years, South Asia, and Sri Lanka in particular, has been hit} hard by the doubling of oil prices. This has added to external and fiscal vulnerabilities as well as inflationary expectations. With high oil prices likely to persist over the medium term, oil-importing countries will need to decide how to cope with the oil shock in the longer run. This set of selected issues papers attempts to assess the impact of the oil shock on South Asian economies, including Sri Lanka, policy responses to deal with the shock, the real income loss for low-income households if fuel subsidies were fully removed, and alternative approaches to mitigate such adverse impact on the poor, as well as whether workers remittances may offer some hedge against future oil shocks in Sri Lanka.

\section{Chapter I reviews the impact of higher world oil prices on South Asian Association} for Regional Cooperation (SAARC) countries and how they have coped with the oil shock to date. It finds that the most important impact has been on the balance of payments. Countries in the SAARC region generally have relied on external borrowing and international reserves to finance higher oil imports. The effect on growth was muted, but there has been some pickup in inflation. Thus far, oil price pass-through has been partial-except in Sri Lanka - and oil subsidies have crowded out productive investment. With high oil prices likely to be permanent, this strategy may not be sustainable and some countries may need to reconsider the balance between financing and adjusting to the oil shock. Those countries with high debts and low external reserves will need to adjust more rapidly.

\section{Chapter II presents the results of the Poverty and Social Impact Analysis (PSIA)} conducted for Sri Lanka in the context of removing oil subsidies. Given that the elimination of subsidies may have an adverse effect on poor households, measures to cushion the impact on vulnerable groups, including social safety nets, may be warranted for social equity reasons. Sri Lanka subsidized petroleum products until September 2006. These subsidies were inefficient and regressive, as evidenced by the substantial leakage to high-income households. The PSIA study shows that the income effects associated with the removal of oil subsidies are high but it would be possible to protect the poor in a more efficient and effective way.

\section{Chapter III explores to what extent Sri Lanka's large receipts of workers} remittances serve as a hedge against shocks, including oil shocks. Amounting to 8.3 percent of GDP in 2005, workers' remittances constitute the largest source of foreign financing in Sri Lanka. Access to this large and relatively stable source of foreign exchange may help reduce vulnerability to shocks. The chapter finds that remittances are procyclical in Sri Lanka, undermining their usefulness as a shock absorber upon deterioration in economic fundamentals. On the other hand, remittances receipts are correlated with oil prices, providing a welcome hedge against oil shocks. While remittances can yield important economic benefits to Sri Lanka and it is important to continue facilitating inflows - with policies directed at reducing transaction costs, promoting financial development, and improving the business climateremittances should not be seen as a substitute for government policy and reform. 


\section{Macroeconomic Challenges of High OIl Prices in the South Asian Region ${ }^{1}$}

\section{A. Background}

1. Over the past two and a half years, South Asia has been hit particularly hard by the doubling of world oil prices. Its terms of trade deteriorated by 7 percent during 2004-05, and it is projected to deteriorate by another 5 percent in 2006 , reflecting higher import prices for oil and lower prices for garment exports after the Multifiber Agreement expired. This contrasts with a much smaller decline of about $3 \frac{1}{2}$ percent in the terms of trade of Asia as a whole and about $1 \frac{1}{2}$ percent for developing countries as a group, with many of them benefiting from higher nonfuel commodity prices. In addition, because of high oil intensity (the ratio of

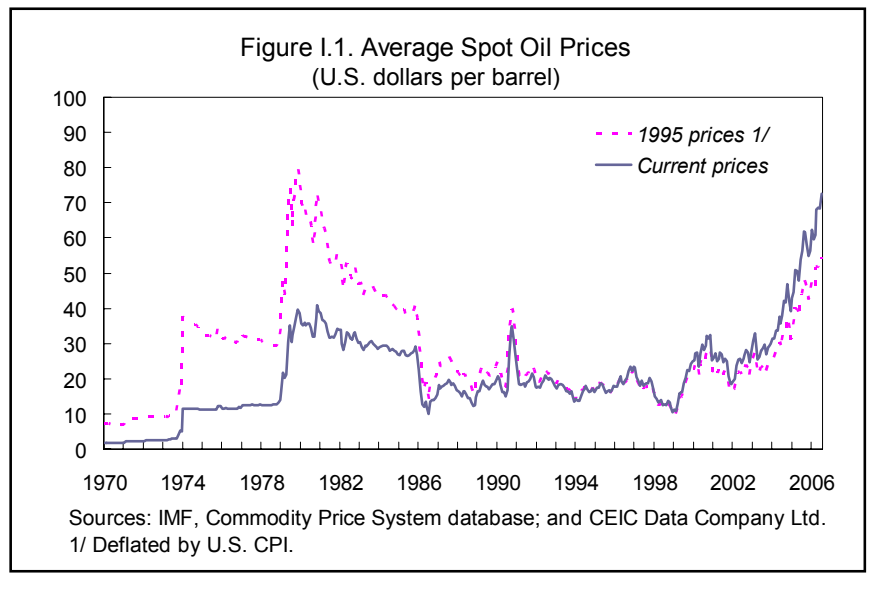
oil imports to total energy consumption), South Asia's net oil imports rose more sharply than those of other Asian countries as a whole.

2. Exports and remittances helped mitigate the impact of higher oil prices on South Asia's external current account, but non-oil imports were also buoyant. Despite falling textile and clothing prices, non-oil exports rose as a share of GDP in five of the six countries in the South Asia region. In some countries, workers' remittances increased as well, aided by the outpouring of help after the tsunami (Sri Lanka) and the fact that many of South Asians work in oil producing countries. However, non-oil imports also boomed, contributing to higher current account deficits than could be accounted for by increased net oil imports.

3. Looking forward, the oil prices are expected to remain volatile as the oil market continues to be tight. Supply constraints and strong growth momentum around the world are likely to give rise to upside risks on oil prices. At current level of $\$ 60$ per barrel, the South Asian countries are expected to continue to face pressures on the balance of payments. Moreover, with economies closer to capacity, oil price increases may create stronger inflationary pressures.

\footnotetext{
${ }^{1}$ Prepared by Erik Lueth and Marta Ruiz-Arranz.
} 


\section{B. Impact of the Oil Shock ${ }^{2}$}

\section{The most important impact of higher oil prices on the South Asian region was on the balance of payments.}

- The terms of trade of South Asian countries (excluding Bhutan and Nepal) declined by about 7 percent on average during 2004-05, compared to $3 \frac{1}{2}$ percent for Asia as a whole (Figure I.2). The oil shock came at a time when many South Asian countries also had to cope with the impact of the expiration of the Multifiber Agreement (MFA) in 2004. At the same time, South Asian countries did not benefit from the improved nonfuel commodity prices enjoyed by commodity-exporting countries. In contrast to the

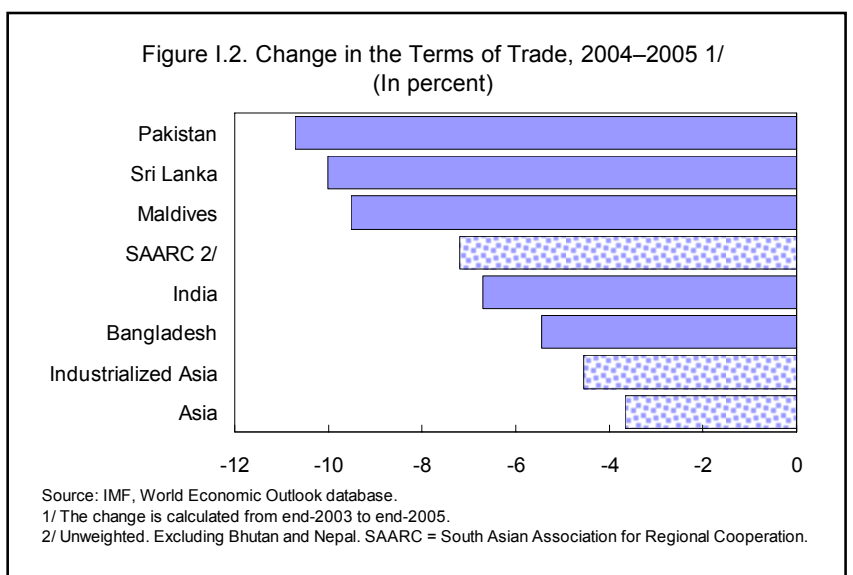
deterioration experienced by South Asia, the terms of trade was virtually unaffected during 2004-05 for oil importing countries as a group, and deteriorated by only $1 \frac{1}{2}$ percent for developing countries as a group.

- $\quad$ South Asian countries net oil imports rose by 2.5 percent of GDP during 2004-05, compared with 1.2 percent of GDP for Asia as a whole, reflecting its high oil intensity in economic activities.

- $\quad$ The oil shock amounted to about 25 percent of South Asian countries overall external reserves in 2003. This contrasts with 30 percent for low-income Asian countries and 8 percent for Asia as a whole.

\section{The impact of higher oil prices on growth in the South Asia region has been muted, but there was a push on inflation.}

- $\quad$ The oil shock coincided with a pickup in growth across South Asia (except Maldives which experienced major damage from the tsunami) (Figure I.3). Countries responded to the oil shock through a mix of financing and adjustment, and the output effects were also mitigated by monetary and fiscal accommodation in some cases.

\footnotetext{
${ }^{2}$ Most of the analysis for the South Asian region was limited to the period of 2004-05 for which country-wise data are available.
} 


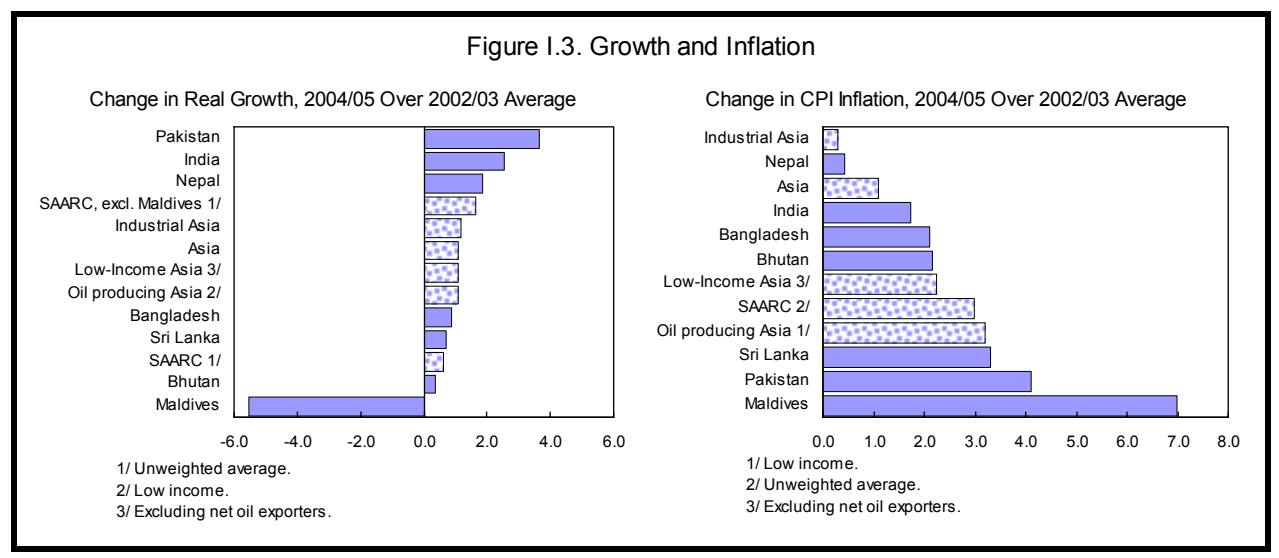

- $\quad$ Domestic price adjustments were limited in many South Asia countries during 2004-05, and implicit or explicit subsidies helped contain the impact of the oil shock on inflation. However, as world oil prices continue to rise, some of these economies implemented more aggressive price adjustments since early 2006. This is the case of Sri Lanka, with an average increase of 35 percent in domestic prices. Inflation rates have picked up, reflecting in part the effect of the price

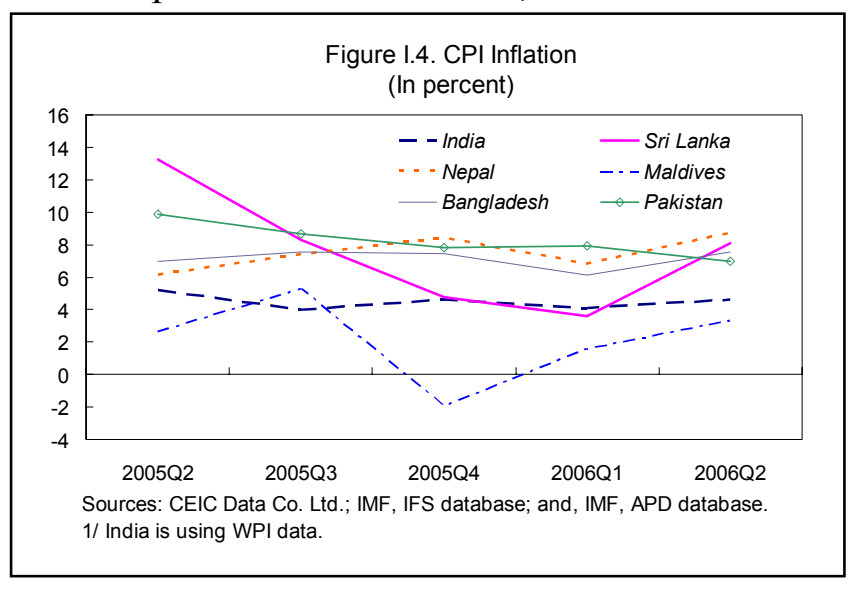
pass-through, but they remain manageable (Figure I.4). The weight of petroleum products and related services (including transport and electricity) in the CPI in SAARC is about 10 percent, comparable to other Asian countries.

\section{Cope With the Oil Shock}

6. How has South Asia responded to the oil shock? During 2004-05, most South Asian economies financed their current account deficits through external borrowing-usually by the government, with the exceptions of Bhutan and Maldives, where capital grants played a significant role. India enjoyed a surge in private capital flows during this period, which helped finance the oil shock and build up reserves. The reserve coverage of imports declined in nearly all South Asian countries - with reserves in Bangladesh, Sri Lanka, and the Maldives falling below the equivalent of 3 months of imports (Table I.1). 


\begin{tabular}{|c|c|c|c|c|c|c|c|c|}
\hline \multicolumn{9}{|c|}{$\begin{array}{l}\text { Table I.1. Financing of the Oil Price Shock } \\
\text { (In percent of GDP; annual average 2004-2005) }\end{array}$} \\
\hline & $\begin{array}{l}\text { Current Account } \\
\text { (1) }\end{array}$ & $\begin{array}{l}\text { Capital Account } \\
(2)=(3)+(4)+(5)\end{array}$ & $\begin{array}{c}\text { Grants } \\
\text { (3) }\end{array}$ & $\begin{array}{l}\text { Borrowing } \\
\text { (4) }\end{array}$ & $\begin{array}{l}\text { Other } \\
(5)\end{array}$ & $\begin{array}{l}\text { Change Reserves } \\
\qquad(6)=(1)+(2)\end{array}$ & \multicolumn{2}{|c|}{$\begin{array}{l}\text { Memo Item: } \\
\text { International Reserves } \\
\text { (months of imports) } 1 /\end{array}$} \\
\hline Bangladesh & -0.3 & 0.8 & & 0.9 & & 0.5 & 2.9 & 2.7 \\
\hline Bhutan & -14.2 & 16.8 & 11.7 & 11.5 & -6.4 & 2.6 & 18.8 & 11.9 \\
\hline India & -2.0 & 4.3 & 0.0 & 1.8 & 2.5 & 2.3 & 8.7 & 9.2 \\
\hline Maldives & -26.6 & 28.1 & $\ldots$ & 10.2 & & 1.5 & 2.7 & 2.6 \\
\hline Nepal 2/ & 4.3 & -2.0 & 0.3 & 2.7 & -5.0 & 2.3 & 6.6 & 6.3 \\
\hline Pakistan 3/ & -1.0 & -0.6 & 0.0 & 0.8 & -1.4 & -1.7 & 6.9 & 4.4 \\
\hline Sri Lanka & -4.0 & 4.4 & 1.3 & 3.4 & -0.3 & 0.4 & 2.8 & 1.8 \\
\hline SAARC $4 /$ & -6.3 & 7.4 & $\ldots$ & 4.5 & $\ldots$ & 1.1 & 7.1 & 5.6 \\
\hline Low-income Asia 5/ & -1.8 & 2.5 & w... & $\ldots$ & $\cdots$ & 0.7 & $\ldots$ & $\ldots$ \\
\hline Industrial Asia & 2.1 & -0.5 & $\ldots$ & $\ldots$ & $\ldots$ & 1.7 & $\ldots$ & $\ldots$ \\
\hline Asia & 3.1 & 1.0 & $\cdots$ & $\cdots$ & $\cdots$ & 4.1 & $\cdots$ & $\cdots$ \\
\hline Oil producing Asia 6/ & -2.4 & 5.4 & $\ldots$ & $\ldots$ & $\ldots$ & 3.0 & $\ldots$ & $\ldots$ \\
\hline $\begin{array}{l}\text { 1/ International reserve } \\
\text { 2/ The large negative } \\
3 \text { / Stock of internation } \\
\text { 4/ Unweighted averag } \\
5 / \text { Excluding net oil ex } \\
\text { 6/ Low income. }\end{array}$ & $\begin{array}{l}\text { s in next year's imf } \\
\text { ther item is assum } \\
\text { I reserves in the la } \\
\text { orters. }\end{array}$ & $\begin{array}{l}\text { orts of goods and } \\
\text { ed to be capital fligh } \\
\text { st two columns refe }\end{array}$ & 'actor serv & d-2005. & & & & \\
\hline
\end{tabular}

7. Healthy economic growth in 2004-05, however, helped offset increased borrowing. For most countries in South Asia (except for Bhutan and Maldives), external debt fell as a share of GDP. Nevertheless, with external debt above 45 percent of GDP in the majority of countries, indebtedness remains at vulnerable levels and is higher than the Asian average of about 30 percent of GDP

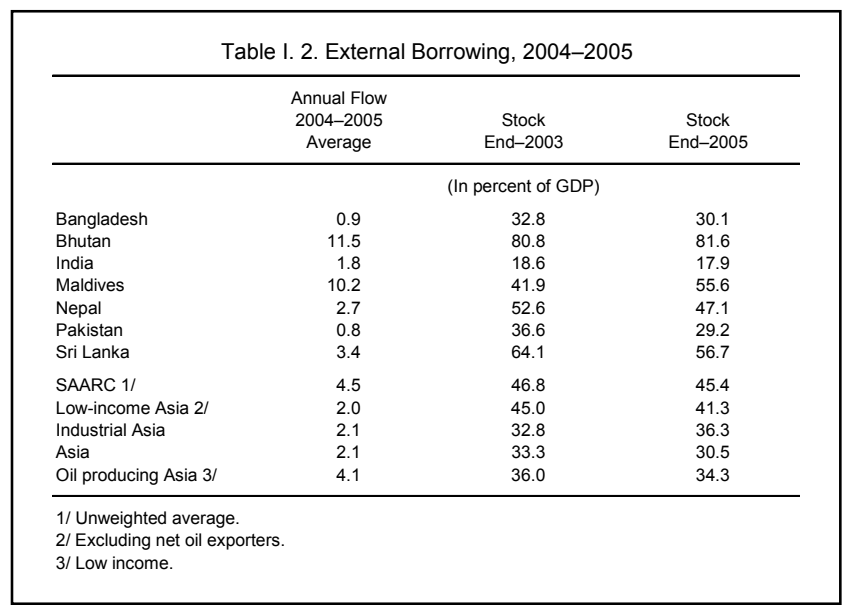
(Table I.2).

\section{South Asian countries also responded to the oil shock by raising administered}

fuel prices. On average, they achieved full price pass-through for gasoline, but lagged by significant margins for diesel and kerosene. Their adjustment is comparable to industrial Asia's and more ambitious than that of other regions (Figure I.5). ${ }^{3}$ However, for diesel, the average pass-through has been 80 percent at end-2005 and it is ahead of other regions. For kerosene, the average pass-through has been around 50 percent, which is similar to that for low-income Asia. As the average world oil price (APSP) continued to climb since early 2006 to about $\$ 76$ per barrel in early August from $\$ 62$ per barrel in January, South Asian countries

${ }^{3}$ Figure I.5 depicts pass-through as the absolute change in domestic retail prices between end-2003 and end-2005 as percent of the absolute change in world prices over the same period. 
Figure 1.5. Domestic Oil Price Developments

Gasoline Pass-Through, 2004-2005 1/

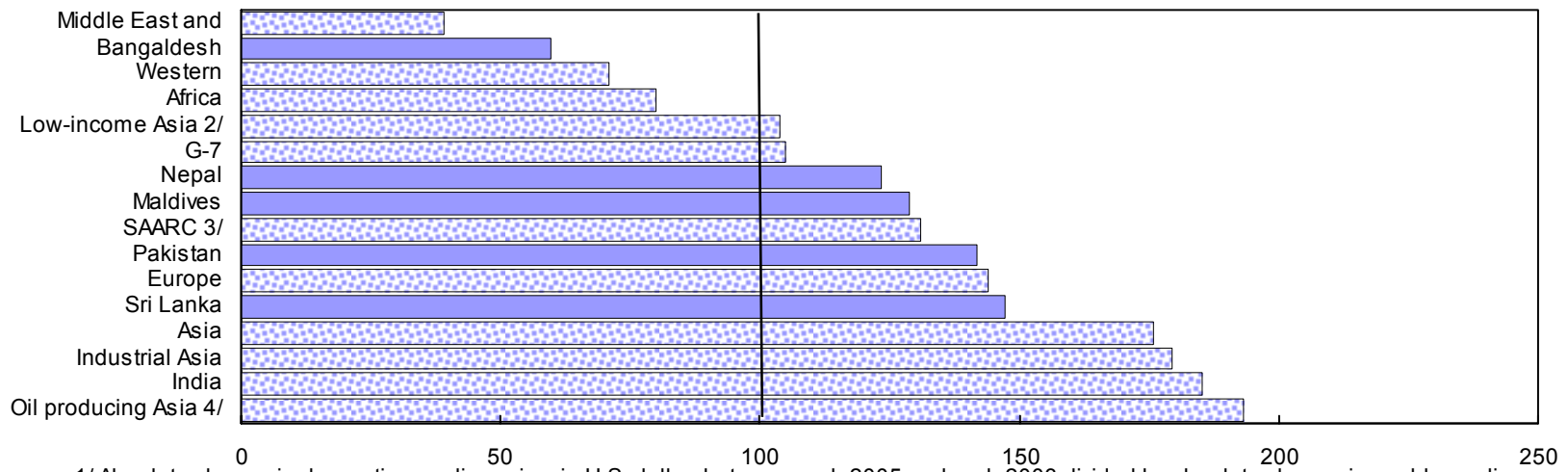

$1 /$ Absolute change in domestic gasoline price, in U.S. dollar, between end-2005 and end-2003 divided by absolute change in world gasoline price over the same period, times hundred.

2/ Unweighted average.

3/ Excluding net oil exporters.

4/ Low income.

Diesel Pass-Through, 2004-2005 1/

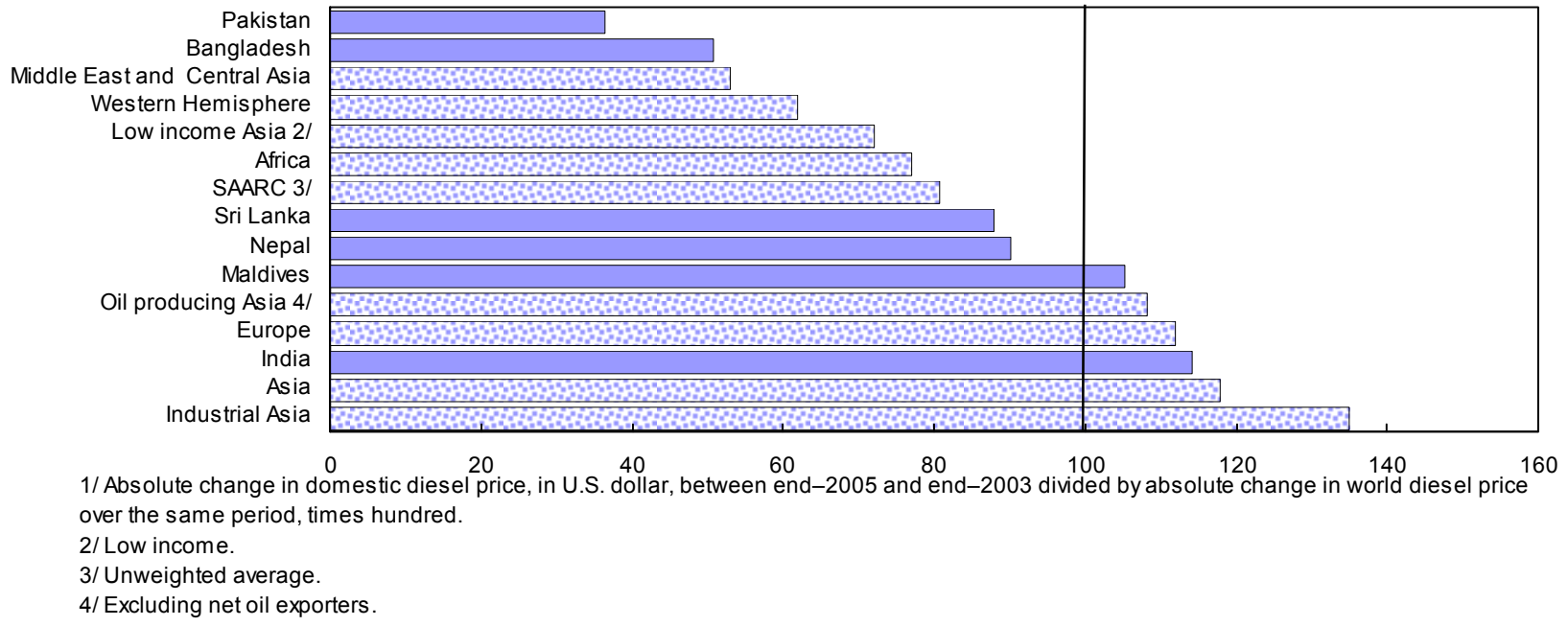

Kerosene Pass-Through, 2004-2005 1/

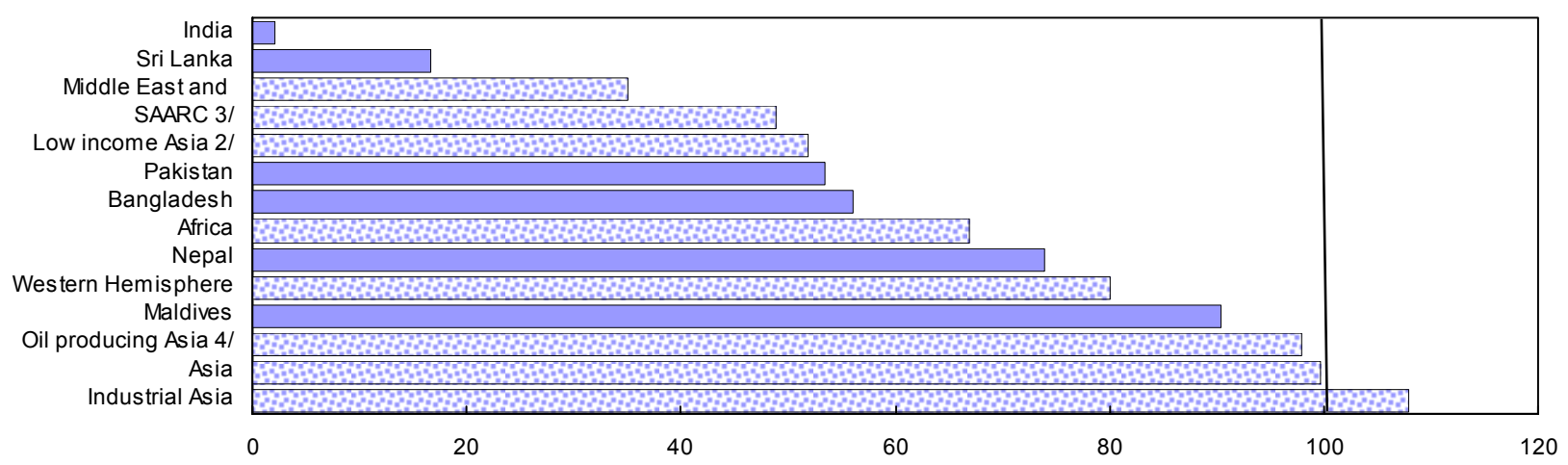

1/ Absolute change in domestic kerosene price, in U.S. dollar, between end-2005 and end-2003 divided by absolute change in world kerosene price over the same period, times hundred.

2/ Excluding net oil exporters.

$3 /$ Unweighted average.

4 / Low income. 
have further adjusted domestic fuel prices, but most of them are still lagging behind the amounts required for full pass-through in kerosene. Sri Lanka has achieved full pass-through for diesel and substantially increased domestic price for kerosene by September. To avoid amplifying price shocks, the Sri Lankan authorities also removed the ad valorem tax of 15 percent on diesel and revised the pricing formula for the two oil companies to ensure cost recovery and a profit margin for future price adjustments.

9. Nevertheless, the incomplete pass-through for diesel and kerosene since 2004 has taken a toll on public finances. Total oil subsidies amount to 0.8 percent of GDP on average during 2004-05 for South Asian economies compared with an average of 0.4 percent of GDP for Asia as a whole (Figure I.6). Moreover, budgeted oil subsidies in South Asia accounted for about 20 percent of the total, implying a substantial amount of quasi-fiscal subsidies. Much of this quasi-fiscal cost was financed by borrowing from the state-owned banks, delayed payments to suppliers, and profit and equity erosion of state-owned enterprises in the energy sector.

\section{In fiscal and monetary policy, the region has made a limited adjustment to the}

oil shock. During 2004-05, fiscal policy was eased or remained the same in all but two South Asian countries (India and Nepal), and money growth picked up in four (Bangladesh, Bhutan, India, and Sri Lanka) (Figure I.7). Moreover, with the exception of Bangladesh, real effective exchange rates appreciated in all South Asian countries, contributing to the strong growth of non-oil imports.

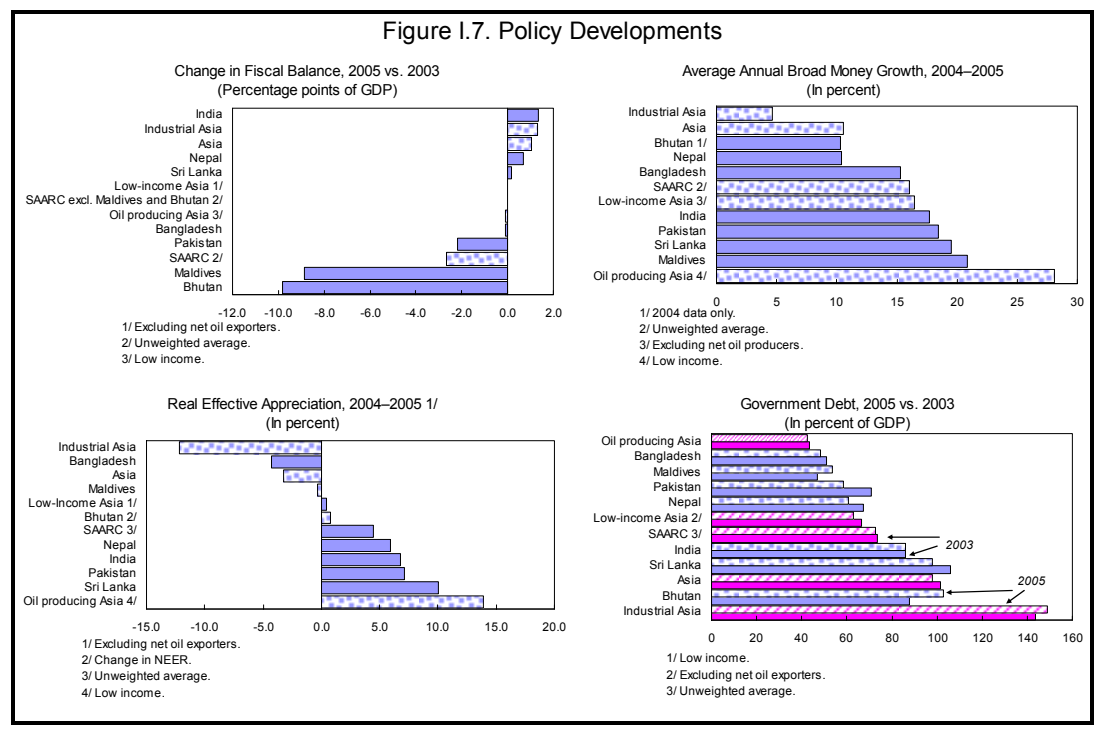




\section{Policy Options}

\section{A permanent terms of trade shock eventually requires macroeconomic}

adjustment. But the optimal speed of that adjustment is determined by a country's access to external financing, its level of international reserves, constraints imposed by external and public debt, and its stage in the business cycle. With oil price likely to remain higher, the full pass-through to domestic consumers is the best policy on both fiscal and efficiency grounds. Subsidization of petroleum products can crowd out productive expenditures, increase public debt, and undermine the financial position of public enterprises. Below cost prices also create distortions (for example, using kerosene to adulterate diesel) and prevent the adjustment in domestic demand that facilitates a return to a sustainable external balance. In the longer term, correct price signals induce countries to adopt alternative energy sources and pursue more energy-efficient technologies, which will serve the countries when they face future oil shocks.

\section{Countries with weak external positions, financing constraints, and adverse debt} dynamics would need to adjust more rapidly to the oil shock. In these countries, there is likely to be less external financing available to their private or public sectors to help cushion their adjustment, and central bank credibility tends to be lower. This necessitates extra caution in monetary policy. Within the overall fiscal adjustment, some support is likely to be needed to protect vulnerable groups. Real exchange rate depreciation would also facilitate adjustment to the oil shock. Countries with flexible exchange rate regimes could generally allow nominal depreciation, while those with fixed exchange rate regimes (or peg to a major currency or a regional currency) will have to rely more on a reduction of domestic absorption in the short term and on downward adjustment of domestic wages and prices to achieve real depreciation over the longer term.

13. Depending on the availability of external concessional financing, low-income net oil importers may be among those that need to adjust more rapidly. Their limited access to foreign capital markets and frequently low levels of reserves would, in many instances, prevent a significant smoothing of their adjustment to the shock. In these cases, increased financing from official sources would help cushion the impact in the short run. However, especially for countries facing already high debt and debt service burdens, such financing would usually lead to the higher debt service burden as the oil financing is unlikely to be given on long term and concessional terms.

\section{Some countries, for social equity reasons, have not passed on the full cost of oil}

price increases. But subsidies are typically inefficient and regressive, as evidenced by the substantial leakage of existing subsidies to high-income households. A more efficient and effective way to help the poor is to eliminate oil subsidies, use some of the proceeds to compensate them through well-targeted safety nets, and still record budget savings. However, it is recognized that the design of effective compensation schemes are a challenge task. 
15. With the recognition of the need for full price pass-through, considerations should be given to the pricing mechanism for oil products. International experience shows that countries with liberalized prices or automatic fuel pricing mechanisms have the highest degree of pass through. In contrast, countries with systems of ad hoc changes take longer to adjust prices upward and the size of the adjustment is smaller.

16. The formulas used to determine price changes should be transparent and based on the international prices of petroleum products. To be transparent, the adjustment formula should be clearly specified and fully documented. International prices are an appropriate benchmark because they provide a measure of the opportunity cost of fuel consumption. To reduce the volatility of prices, a moving average for the reference price could be used. It is generally recommended that prices be adjusted monthly which is preferable to avoid sharp increases.

\section{Where excise taxes on petroleum products are on an ad valorem basis,} consideration could be given to converting them to specific rates. Ad valorem taxation can increase tax revenues procyclically in oil-importing countries, placing the burden of an additional adjustment on the private sector. Where the level of ad valorem excises prior to the recent oil price increases was already appropriate from the point of view of conservation and fiscal needs, it might be reasonable to make the switch to specific rates on a revenue neutral basis.

\section{Some countries are also concerned about the impact of full pass-through on} growth. But delaying adjustment unduly is also not without risks since it could induce a larger and more abrupt adjustment later on, with possibly worse effects on growth. In the case of Indonesia, for example, domestic retail prices were raised by 30 percent in March 2005 - the first adjustment after a long delay against the doubling increases in international prices since 2002. At the same time, monetary conditions were loose and real interest rates turned negative. In this environment, capital outflows picked up and reserves coverage reached critical levels. In October 2005, the Indonesian authorities embarked on a large adjustment to avert a potential balance of payments crises. Oil prices were raised between 90 percent (gasoline) and 200 percent (kerosene) on a single day and policy rates were jacked up by 425 basis points between August and December, complemented by a program to compensate the poor. As a result, the monthly growth of oil and gas imports decelerated sharply during that period (to 3 percent in November from an average of over 50 percent during January-August). However, real growth slowed-from 6.1 percent in the first quarter of 2005 to 5.3 percent in the third quarter, and an expected 4⿳⿲丶丶㇒一八 


\section{E. Conclusion}

19. With high oil prices likely to persist over the medium term, South Asian countries need to reconsider the balance between financing and adjustment to the oil shock. Those countries with high debts and low external reserves will need to adjustment more rapidly. As experience has shown, a determined and timely adjustment is preferable to a large and disruptive one and eventually helps to minimize the negative effects often associated with external shocks. 


\section{The FisCAL AND Distributional IMPACTS OF FUEL SUBSIDY REFORM AND Alternative Mitigating Measures ${ }^{4}$}

\section{A. Summary and Introduction}

\section{Sri Lanka has recently moved towards full pass-through of oil prices and} automatic pricing adjustments for petroleum products. World oil prices more than doubled in the past two years. In 2005, in spite of a series of increases in domestic fuel prices, fuel subsidies remained at an estimated 1.1 percent of GDP while quasi-fiscal losses generated from administered electricity charges were around $1 / 2$ percent of GDP. The 2006 budget targeted removing fuel subsidies through price adjustments. Domestic fuel prices were increased in April, June, August, and September 2006, completing the full pass-through for petrol and diesel, and substantially reducing subsidies for kerosene. The pricing formula for fuel products was also revised in September to set the stage for oil companies to determine domestic prices from September onwards.

\section{Reducing fuel subsidies is desirable from both fiscal and efficiency perspectives.} Fuel subsidies can crowd out desirable social expenditures. For example, the budget cost of the main safety net program (the Samurdhi program), at 0.4 percent of GDP, is substantially smaller than fuel subsidies. In 2005, government expenditures on health and education were 1.9 percent and 2.6 percent of GDP, respectively. In addition, subsidizing domestic fuel prices is not conducive to energy efficiency and creates potential fiscal and external risks.

\section{However, the fiscal and efficiency gains from higher domestic prices obviously} come at the cost of lower real income for households. This raises the issue of how best to mitigate the impact of fuel price adjustments on the poor. ${ }^{5}$ This chapter simulates the likely magnitude of the real income loss for households resulting from the price increases required to move to formula pricing starting from the prices that existed in July 2006. The simulated price increases therefore mirror the actual price increases that occurred in August and September 2006 with the exception that the subsidy to kerosene is completely eliminated.

\footnotetext{
${ }^{4}$ Prepared by David Coady and David Newhouse, Poverty and Social Impact Analysis (PSIA) Group, Fiscal Affairs Department. The authors are extremely grateful to the following persons for useful discussions and providing ready access to background documents and data: Matt Davies, Olin Liu, Erik Lueth, Shehan Ramanayake, and Marta Ruiz-Arranz (all IMF), Amber Narayan, Tara Vishwanath and Nobuo Yoshida (all World Bank). The authors also benefited from discussions with the authorities and other development stakeholders, including the Institute for Policy Studies and the Munasinghe Institute for Development, during a presentation of the findings at a workshop in Sri Lanka in July 2006.

${ }^{5}$ The headcount poverty rate based on the official national poverty line was estimated as nearly 23 percent in 2002 (World Bank, 2005).
} 


\section{The chapter also identifies options for mitigating these adverse impacts on}

low-income households. These could include: (i) differential pricing of petroleum products, especially kerosene which is an important source of energy for the poor; (ii) the use of lifeline electricity tariffs; and (iii) the allocation of some of the budgetary savings to existing safety net transfer programs (such as the Samurdhi program). The analysis therefore builds on existing work being undertaken at the World Bank with regard to broader energy sector restructuring and reform of the existing system of social assistance.

\section{The main conclusions of the analysis are as follows:}

- $\quad$ The fuel subsidies that Sri Lanka maintained until July 2006 were regressive as well as being inefficient, as evidenced by the substantial leakage to high-income households. About 52 percent of the subsidies went to the top two income quintiles compared to only 31 percent to the bottom two-income quintiles. Therefore, it cost the budget approximately Rs. 3.2 to transfer Rs. 1 to the poorest 40 percent of households via fuel subsidies.

- The household welfare loss from the full pass-through of oil prices is estimated at about a 1.2 percent decrease (on average) in household real incomes. Households in the bottom income quintile would experience on average a 1.8 percent decline in their real incomes compared to a 1.0 percent decrease for the top income quintile.

- Kerosene is a relatively important source of energy for poor households, but the bulk of kerosene subsidies still leak to nonpoor households. Over 34 percent of kerosene subsidies accrue to the top two quintiles and it costs the budget Rs. 2.2 to transfer Rs. 1 to the poorest two quintiles via kerosene subsidies. In addition, maintaining kerosene subsidies while removing other fuel subsidies is likely to result in inefficient substitution towards kerosene away from other fuels (especially diesel), resulting in a second-round increase in the subsidy bill.

- Increased domestic fuel prices could lead to higher quasi-fiscal losses of the power sector if electricity tariffs were not adjusted. Given the low access rates to electricity for poor households, most of the benefits of the current subsidies have accrued to middle-income households. The leakage of the electricity subsidies in the current system of tariffs is even greater than that for kerosene subsidies, with the top income quintile receiving half the aggregate subsidy compared to less than 6 percent to the bottom income quintile.

- As an illustration, an alternative option to protect the poor from price adjustments is to use the budgetary savings to expand the existing Samurdhi program. Only 19 percent of Samurdhi transfers leak to the top two quintiles, coverage of the poorest households is high, and it costs the budget Rs. 1.7 to transfer Rs. 1 to the poorest 40 percent of households. A better-targeted transfer program could decrease leakage 
and increase coverage, and decrease the budget cost to less than Rs. 1.4 per rupee transferred to the poorest 40 percent of households.

6. The format of the paper is as follows. Section B discusses the structure of energy pricing in Sri Lanka and motivates the price increases to be simulated in the analysis. Section $\mathrm{C}$ describes the approach used to evaluate the magnitude and distribution of the real income losses due to these price increases as well as the data sources used in the analysis. Section D presents estimates of the likely real income effects of eliminating energy subsidies. Section E compares the relative effectiveness of alternative approaches to mitigation in terms of how well they protect the poorest households from the adverse effects of price increases. Section $\mathrm{F}$ discusses the potential for mitigation policies specifically aimed at addressing increases in agricultural production costs and household transport costs. Section $\mathrm{G}$ provides some concluding comments.

\section{B. The Structure of Energy Prices}

\section{Prior to September 2006, domestic prices of petroleum products in Sri Lanka} had not been increased in line with the substantial increases in import prices. Until early 2002 , domestic petroleum prices were adjusted on an ad hoc basis and motivated primarily by fiscal constraints. In February 2002, a pricing formula was introduced (for kerosene, petrol, diesel and fuel oil), which linked domestic prices to world prices and triggered domestic price adjustments whenever the formula price deviated from the actual price by Rs. 0.25 per liter. ${ }^{6}$ Price adjustments were in principle monthly and also limited to a maximum of Rs. 2 two per liter. However, fuel subsidies were reintroduced in February 2003 in the face of continued increases in international oil prices. Since then the formula has been used solely to determine the magnitude of the budget subsidy to importers and distributors. Losses not covered by the budget have been allowed to be offset against corporate tax payments (as in the case of the state enterprise, Ceylon Petroleum Corporation) or have been absorbed by distribution companies (as in the case of the privately owned Lanka IOC).

\footnotetext{
${ }^{6}$ The reform in pricing policy was introduced as part of a package of reforms that also allowed private sector participation in the import and distribution of petroleum products, which was previously the exclusive domain of the Ceylon Petroleum Corporation (CPC). In 2003, a subsidiary of the Indian Oil Company (Lanka IOC) was allowed to import and distribute fuel products and now controls approximately one third of all retail outlets.
} 


\section{Price increases in August and September 2006 have virtually completed full} pass-through for petrol and diesel, while substantially reducing subsidies for kerosene. Figure II. 1 shows the structure of the revised pricing formula based on the benchmark import prices of August 2006, indicating that kerosene subsidies remain at about 40 percent. $^{7}$ During April-September, domestic fuel prices increased by about 35 percent (weighted average), reducing the current fuel subsidies to less than 0.1 percent of GDP. Value added tax on diesel was removed in

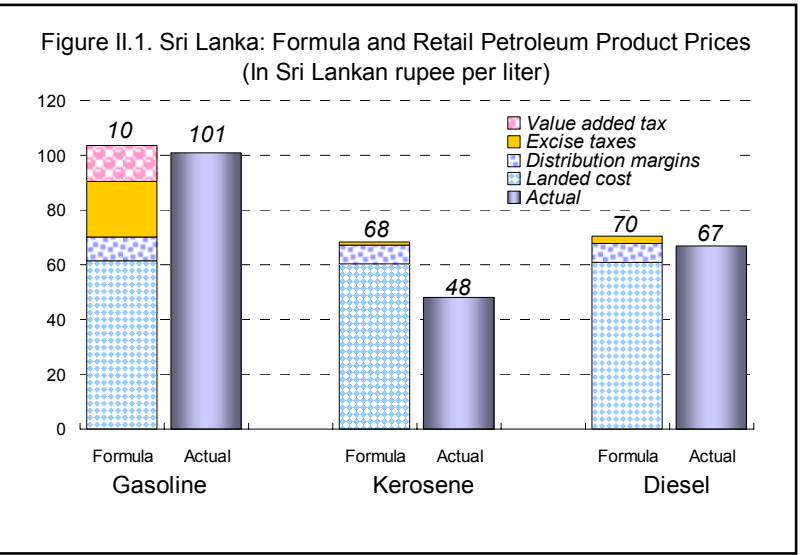
August 2005.

\section{Methodology and Data}

9. Estimating the likely impact of higher fuel prices on household real incomes requires an estimation of both the direct effect due to higher prices for fuel products consumed directly by households as well as the indirect effect due to increases in the prices of other goods and services consumed by households. ${ }^{8}$ For each household, multiplying each price increase by the share of the corresponding good or service in total household expenditures gives an estimate of the percentage decrease in household real income due to that price change. For example, if the price of petrol increases by 20 percent and the share of petrol in total household expenditures is 5 percent then the price increase leads to a 1 percent decrease in the real income of the household. For each household, these real income effects are aggregated across all price increases to get the total decrease in household real income, which can be separated into that due to the direct effect (i.e., due to increases in the prices of energy consumed directly by households) and that due to the indirect effect (i.e., due to increase in the prices of other goods and services that use petroleum products in their production).

10. To analyze the distribution of the real income effect, each household is allocated to a welfare quantile, where household per adult equivalent consumption is used as the

\footnotetext{
${ }^{7}$ Latest developments in world oil markets since the analysis was undertaken might have changed the magnitude of these figures slightly.

${ }^{8}$ The estimation of the indirect price effect on other goods and services assumes that all cost increases are pushed forward onto output prices. Since much of the cost increases come through trade and distribution margins, which are nontraded, this is probably a good approximation. However, in the context of agriculture, we also consider the implications of not being able to fully push higher fuel costs onto output prices.
} 
welfare criterion. The real income impact is then averaged over all households in each quantile to get the average percentage decrease in household real income in each quantile. If this average is relatively high (low) for low-income households, then the price changes are seen as regressive (progressive). Regressivity (progressivity), therefore, implies that the share of low-income households in the aggregate real income loss is greater (less) than their share in aggregate income.

\section{Low energy prices are often justified as a way of protecting the real incomes of} poor households. Therefore, it is important to compare the protection afforded by these subsidies to that which would be afforded by alternative approaches to social protection. To evaluate the cost effectiveness of fuel subsidies at protecting low-income households, the share of the aggregate fuel subsidies accruing to each quantile is calculated. As an illustration, if the poorest 40 percent of households receive only 20 percent of the aggregate fuel subsidy then this implies that it costs the budget Rs. 5 to transfer Rs. 1 to these households (i.e., Rs. 100/Rs. 20). This measure is compared across alternative approaches to protecting low-income households. If more cost-effective approaches can be identified then the same level of protection can be achieved at much lower cost with a resulting improvement in the government's budgetary position (i.e., a net decrease in budgetary expenditures including both subsidy expenditures and transfer expenditures).

\section{The analysis of the likely magnitude and distribution of the household real} income decrease resulting from the removal of energy subsidies uses two main data sources. Firstly, the estimation of the price increases for goods and services due to higher fuel prices uses information on the input-output structure of the economy. This is taken from an input-output table for 2001 provided by the Institute for Policy Studies (Amarasinghe and Jayatilleke, 2005), which provides information on the cost structures of 40 sectors in the economy. Secondly, the estimation of the real income effects of price increases for fuel and other goods and services uses expenditure information available in the Sri Lanka Integrated Survey for 1999 (SLIS1999). The SLIS1999 also contains information on receipt of the Samurdhi program which is used to simulate the targeting performance of this program as well as to simulate that for a "new improved" transfer program with eligibility based on a model similar to that being developed by the World Bank. Where possible, estimates based on SLIS1999 were compared with those based on the Household Expenditure and Income Survey for 2001 and similar results were found.

\section{The Impact of Fuel Subsidy Reform}

13. This section illustrates the likely impact on households' real incomes of the price increases required under the September 2006 pricing formula. Starting from the actual domestic prices of July 2006, at per liter prices of Rs. 93 for petrol, Rs. 61 for diesel, and Rs. 43.5 for kerosene, the corresponding required formula prices (based on August 2006 import prices) were Rs. 104, Rs. 70, and Rs. 68 respectively. These prices provide the basis of the simulated price increases of 11.5 percent for petrol, 15.3 percent for diesel and 
57.2 percent for kerosene. They approximate the actual full pass-through in August and September, with the exception of kerosene for which the prevailing price (at Rs. 48.5 per liter) is lower than the full pass-through price used in the simulation.

\section{The level and composition of energy consumption varies substantially across} households at different parts of the income distribution. Figure II. 2 presents the budget shares for petroleum products and electricity using the information available in the SLIS1999. On average, households allocate 3.4 percent of their total consumption (approximately Rs. 927 per month) to these energy sources, mostly to kerosene (1.1 percent) and electricity (1.3 percent). ${ }^{9}$ But this average masks substantial variation across income groups. Whereas the bottom three quintiles allocate between 2.5-3.0 percent of total consumption to energy (i.e., Rs. 180-250 per month); the top two quintiles allocate between 3.7-5.3 percent (i.e., Rs. 546-1,445 per month). The energy budget share was also found to be substantially higher for all income groups in urban areas compared to rural areas. In both urban and rural areas, kerosene is more important in the budgets of low-income households whereas electricity, petrol and diesel, and LPG are most important for higher income groups.

\section{The direct income effect on}

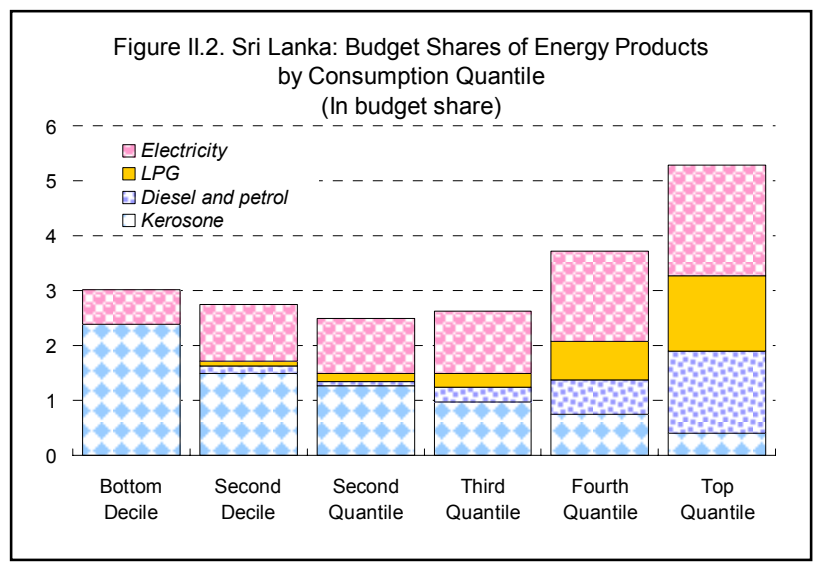

households from increases in fuel prices is higher for low-income households reflecting the substantial increase in the price of kerosene. Figure II.3 presents the average real income impact by quantile in terms of the percentage decrease in household real incomes. On average, the direct effect is equivalent to a 0.7 percent decrease in household real incomes, and this varies from

1.4 percent for the bottom income decile (or Rs. 84 per month) to 0.5 percent for the top income quintile (or Rs. 137 per month). For low-income households, this direct income effect comes almost completely from increased kerosene prices sufficient to completely eliminate kerosene subsidies. For the top quintile,

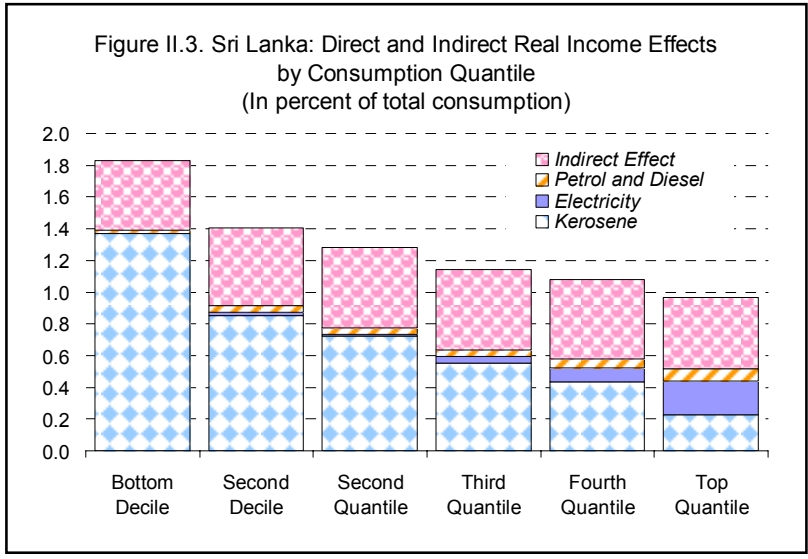
40 percent of the aggregate direct effect comes from price increases for petrol.

\footnotetext{
${ }^{9}$ Throughout this chapter, absolute rupee values are at 2005 prices, calculated by inflating 1999 values by a factor of 1.68 reflecting inflation over the period.
} 
16. The indirect effect on income from increases in the prices of other goods and services is slightly lower than the direct effect but varies very little across income groups. Figure II.3 also presents the average indirect effect and its distribution across income groups. On average, the indirect effect on prices leads to a 0.5 percent decrease in real incomes (or Rs. 75 per month), this being very similar across quantiles. On average, the indirect effect accounts for 42 percent of the total (i.e., direct plus indirect) income impact. The bulk (i.e., around 67 percent) of the indirect effect reflects the indirect effect on processed and nonprocessed food prices combined with the relatively high food expenditure share. The indirect effect coming through increases in prices for services is also relatively substantial.

\section{Although the total effect (i.e., combined direct and indirect effects) on real} incomes is greater for low-income households, high-income households account for a substantially greater share of the aggregate real income loss. The average total effect is equivalent to a 1.2 percent decrease in real incomes and varies from 1.8 percent for the bottom decile (or Rs. 107 per month) to 1.0 percent for the top quantile (or Rs. 275). This pattern reflects the pattern of income effects from the direct effect. However, the top two quintiles account for 52 percent of the total real income loss compared to 31 percent for the bottom two quintiles. The corollary of this is that lower income households receive a relatively low share of the existing subsidy benefits: the subsidy received by the top two quintiles is nearly 1.7 times that received by the bottom two quintiles (i.e., 52/31). It costs the budget Rs. 3.2 for every Rs. 1 transferred the bottom two quintiles via fuel subsidies.

\section{E. Impact of Mitigating Measures}

\section{The results presented above clearly indicate that fuel subsidies are not a} cost-effective approach to protecting the real incomes of low-income households. This section considers alternative options for protecting low-income households and their potential for mitigating the impact of higher domestic fuel prices. We consider three different approaches to social protection:

- $\quad$ Maintaining subsidies only on kerosene. Kerosene is typically much more important in the budgets of poor households than other petroleum products. Maintaining these subsidies is therefore often recommended as a way of mitigating the effect of fuel subsidy reforms on poor households.

- $\quad$ Using some of the budgetary savings from eliminating all fuel subsidies to finance a decrease in the average electricity tariff. Two different approaches are considered. First, the existing tariff schedule is scaled down for all households. Second, the average tariff is similarly scaled down but the tariff schedule is also restructured to decrease the average tariff for low-level users and increase it for high-level users. 
- $\quad$ Using some of the budgetary savings from eliminating all fuel subsidies to finance a targeted transfer program. The effectiveness of this approach will depend on how well the existing Samurdhi program is targeted at poor households. The World Bank is recommending an alternative approach to identifying the poor based on socio-economic characteristics more strongly correlated with poverty status (World Bank, 2005). The analysis therefore considers two alternatives: (i) providing protection using the existing program, and (ii) providing protection using a reformed program.

19. The following analysis illustrates the budget allocations to social protection with budget neutral comparisons. Based on 2005 fuel consumption volumes, annual kerosene subsidies amount to Rs. 6.3 billion as of July 2006, equivalent to nearly 0.3 percent of GDP and around 17 percent of total fuel subsidies. When considering the use of electricity tariff reforms or the Samurdhi program to mitigate the impact of eliminating all (including kerosene) subsidies, the budget cost of these measures is kept at this level.

\section{Although kerosene subsidies are better targeted than other energy subsidies,} there is still substantial leakage of subsidy benefits to high-income households. Nearly 65 percent of households consume some kerosene and thus receive some of the kerosene subsidy. The percentage receiving some subsidy (i.e., coverage) is substantially higher for the lower income deciles compared to the top quintile ( 81 percent versus 45 percent), although the middle quintiles also have relatively high coverage. This high coverage of the poorest households is often seen as a very attractive feature of universal price subsidies. On average, existing kerosene subsidies are equivalent to a 1.4 percent increase in real income for the bottom decile (or Rs. 84 per month) compared to a 0.2 percent increase for the top quintile (or Rs. 54 per month). However, there is still substantial leakage of kerosene subsidy benefits to higher income groups, with just under 54 percent of the total subsidy going to the top three quintiles. It therefore costs the budget Rs. 2.2 to transfer Rs. 1 to the bottom two quintiles using kerosene subsidies, compared to the Rs. 2.8 for all fuel subsidies combined.

\section{Reducing electricity tariffs is even less cost effective than kerosene subsidies} since electricity access is substantially lower in the bottom income quantiles and electricity consumption rises with income. Overall, nearly 62 percent of households have access but this varies from 30 percent for the bottom decile to 88 percent in the top quintile. The actual tariff schedule involves an increasing multi-block structure with tariffs increasing with total electricity consumption levels. Using the budgetary savings from the removal of kerosene subsidies to lower average tariffs for all households with access (i.e., scaling down the existing tariff schedule) would decrease the average tariff from Rs. $3.5 / \mathrm{kWh}$ to Rs. $2.7 / \mathrm{kWh} .{ }^{10}$ However, only 15 percent of the aggregate implicit subsidy would accrue to

\footnotetext{
${ }^{10}$ These rates reflect the tariff in place at the time of the survey data. Note that these tariff levels are substantially below the existing cost recovery tariff for residential consumers, which has been estimated at
} 
the bottom two quintiles so that it costs the budget Rs. 6.7 to transfer Rs. 1 to these households. Restructuring tariffs to lower average tariffs for lower income households and raise them for higher income households (see Figures II.4 and II.5), could improve targeting slightly by increasing the subsidy share accruing to the bottom two quintiles to just under 30 percent. ${ }^{11}$ But this is still substantially less cost effective than kerosene subsidies since it costs the budget Rs. 3.3 to transfer Rs. 1 to this group.
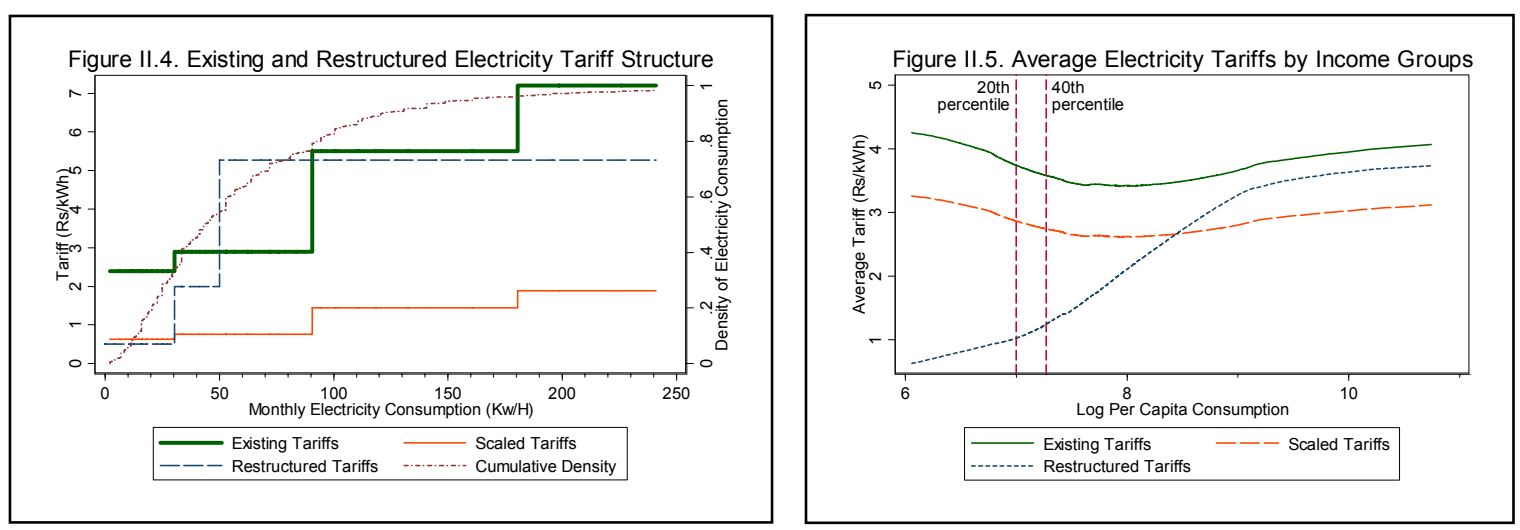

22. An alternative to maintaining kerosene subsidies would be to allocate the budgetary savings from their removal to expanding the existing Samurdhi safety net program. This program was introduced in 1995 (extended to North and East in 1997), and its budget allocation averaged at around 1 percent between 2000-02, but had fallen to 0.4 percent of GDP by 2004 and 2005 (or Rs. 9.4 billion). Eligibility is determined by local administrators through local Samurdhi organizations and in principle is based on their assessment of household income and economic status. The Samurdhi food stamps component is the mainstay of the system. The analysis, therefore, assumes that the budgetary savings from removing kerosene subsidies are allocated to expanding food stamp transfers.

\section{Although the existing Samurdhi transfer program is often criticized as being} badly targeted, it is substantially better targeted than existing kerosene subsidies and has similar coverage of the poorest households. Just over 40 percent of all households receive food stamps, this being much higher for the lower-income quintiles than for the higher-income quintiles so that 56 percent of all recipients come from the poorest 40 percent of households. If the budgetary savings from kerosene subsidies are allocated to existing households in proportion to existing transfers (i.e., to scale up transfers), then this will lead

Rs. 12/kWh (Munasinghe Institute for Development, 2004). The cost recovery tariff is expected to decrease over time with planned investments in more efficient plants.

${ }^{11}$ The results are based on a restructured and simplified schedule with three blocks, with lower rates for the lowest block and higher for the higher blocks. Other more complex structures were tried but without any improvement on the reported structure. 
on average to 0.5 percent increase in household real incomes, varying from 1.4 percent for the bottom decile (or Rs. 83) to 0.1 percent for the top quintile (Rs. 27 per month). Out of total transfers, 32 percent goes to the bottom quintile compared to 24 percent under kerosene subsidies. It costs the budget Rs. 1.7 to transfer Rs. 1 to the two lowest income quintiles.

24. However, if effectively implemented, the new targeting approach suggested by World Bank (2005) for a reformed transfer program could substantially improve its cost effectiveness by both reducing leakage to higher income quintiles and increasing coverage of the bottom quintiles. If the 40 percent of households currently participating in the program were instead selected based on this approach, then the coverage rate for the lowest decile would increase from 67 percent to 84 percent while that for the top two quintiles would decrease from an average of 44 percent to 15 percent. The proportion of total beneficiary households coming from the bottom quintile would increase from 31 percent to 44 percent, while the transfer levels are increased for this group at the expense of lower transfer in the top quintiles. The net result is that leakage of transfers to the top two quintiles decreases from 19 percent to less than 9 percent. With this targeting performance, it costs the budget less than Rs. 1.4 for every Rs. 1 transferred to the bottom two quintiles.

\section{Of the mitigating approaches considered, only the targeted transfer program} fully protects the poorest households from fuel price increases within the simulated program budget. Table II.1 presents the net impact on household incomes of fuel subsidy reform combined with the various mitigating measures, keeping the "mitigation budget" equal to the size of existing kerosene subsidies. Maintaining kerosene subsidies reduces the impact from a 1.8 percent decrease in income for the bottom decile when all subsidies are removed to 0.5 percent decrease when kerosene subsidies are retained. Reducing average electricity tariffs equally for all households, or restructuring the tariff schedule so as to reduce average tariffs for low-level users and increase them for high-level users, provides very little protection to poor households. The average income effect for the poorest decile falls only to 1.3-1.5 percent. Both the existing Samurdhi program and the reformed targeted transfer program provide the highest levels of protection with the net income impact on the bottom deciles being a 0.1 percent decrease in income using the existing program and a 0.7 percent increase in income using the reformed program. 


\begin{tabular}{|c|c|c|c|c|c|c|c|}
\hline \multicolumn{8}{|c|}{$\begin{array}{l}\text { Table II.1. Sri Lanka: Impact of Fuel Price Increases with Compensating Measures } \\
\text { (Percent loss) }\end{array}$} \\
\hline & $\begin{array}{l}\text { Bottom } \\
\text { Decile }\end{array}$ & $\begin{array}{l}\text { 2nd } \\
\text { Decile }\end{array}$ & $\begin{array}{c}\text { 2nd } \\
\text { Quantile }\end{array}$ & $\begin{array}{c}\text { 3rd } \\
\text { Quantile }\end{array}$ & $\begin{array}{c}\text { 4th } \\
\text { Quantile }\end{array}$ & $\begin{array}{c}\text { Top } \\
\text { Quantile }\end{array}$ & $\begin{array}{c}\text { All } \\
\text { Households }\end{array}$ \\
\hline Eliminating all fuel subsidies & 1.8 & 1.4 & 1.3 & 1.1 & 1.1 & 1.0 & 1.2 \\
\hline Maintaining kerosene subsidies & 0.5 & 0.6 & 0.6 & 0.6 & 0.7 & 0.8 & 0.6 \\
\hline Reducing average electricity tariffs for all households & 1.5 & 1.0 & 0.9 & 0.8 & 0.6 & 0.4 & 0.8 \\
\hline Restructuring tariff schedule & 1.3 & 0.8 & 0.7 & 0.6 & 0.6 & 0.6 & 0.7 \\
\hline Existing Samurdhi program & 0.1 & 0.3 & 0.5 & 0.6 & 0.7 & 0.9 & 0.5 \\
\hline Reformed Samurdhi program & -0.7 & -0.1 & 0.3 & 0.6 & 0.9 & 1.0 & 0.4 \\
\hline
\end{tabular}

\section{F. Agriculture and Transport Sectors}

\section{Higher food and transport prices are the two most important channels whereby} households are indirectly affected by higher fuel prices. These sectors are often singled out as areas where specific mitigating measures are warranted. In the context of food, policy makers are often concerned that higher production costs cannot be fully passed on to consumers so that farmers have to absorb these higher costs. In the context of transport, low-income households typically rely relatively more on public transport thus providing the potential for better targeting of transport subsidies. This section addresses these two issues in turn.

\section{Higher fuel prices can increase agricultural production costs through a number} of channels, including higher prices for chemical fertilizers and sprays, higher costs of irrigation and higher costs of using or hiring tractors. Table II. 2 provides information on the prevalence and magnitude of these costs for farmers at different parts of the national income distribution. Use of chemical fertilizer and sprays is very common among farmers at all income levels, averaging around 89 percent. Also, a high proportion of land is irrigated either through a major or minor irrigation scheme at all income levels. Both chemical fertilizer/spray and tractor charges are quite large relative to household income, averaging around 57 percent and 32 percent respectively. 


\begin{tabular}{|c|c|c|c|c|c|c|c|}
\hline & $\begin{array}{l}\text { Bottom } \\
\text { Decile }\end{array}$ & $\begin{array}{l}\text { 2nd } \\
\text { Decile }\end{array}$ & $\begin{array}{l}\text { 2nd } \\
\text { Quintile }\end{array}$ & $\begin{array}{c}\text { 3rd } \\
\text { Quintile }\end{array}$ & $\begin{array}{c}\text { 4th } \\
\text { Quintile }\end{array}$ & $\begin{array}{c}\text { Top } \\
\text { Quintile }\end{array}$ & $\begin{array}{c}\text { All } \\
\text { Households }\end{array}$ \\
\hline \multicolumn{8}{|c|}{ Percentage of households incurring costs or owning assets } \\
\hline Fertilizer costs & 83.8 & 86.8 & 88.1 & 90.6 & 90.5 & 86.9 & 88.5 \\
\hline Irrigation charges & 3.9 & 2.9 & 2.3 & 6.6 & 7.3 & 7.0 & 5.2 \\
\hline Tractor fees & 37.5 & 31.6 & 49.5 & 57.1 & 55.9 & 54.7 & 50.8 \\
\hline Owns diesel pump & 1.2 & 0.0 & 1.2 & 2.5 & 2.5 & 5.8 & 2.4 \\
\hline Owns tractor & 0.0 & 1.4 & 3.7 & 6.4 & 7.5 & 13.7 & 6.2 \\
\hline \multicolumn{8}{|c|}{ Expenditure on farm inputs (percent of total consumption) } \\
\hline Fertilizer & 52.1 & 59.5 & 59.5 & 57.4 & 58.9 & 52.1 & 57.3 \\
\hline Irrigation & 0.3 & 0.2 & 0.3 & 0.6 & 1.1 & 0.7 & 0.6 \\
\hline Tractor chargers & 22.3 & 20.2 & 39.9 & 37.0 & 28.9 & 27.9 & 32.1 \\
\hline \multicolumn{8}{|l|}{ Share of total costs } \\
\hline Fertilizer & 3.2 & 7.1 & 19.7 & 22.7 & 22.5 & 24.9 & 19.3 \\
\hline Irrigation & 1.7 & 2.6 & 10.6 & 22.1 & 32.4 & 30.5 & 20.2 \\
\hline Tractor chargers & 3.1 & 5.0 & 24.5 & 27.0 & 21.8 & 18.6 & 19.4 \\
\hline \multicolumn{8}{|c|}{ Percentage of land cultivated irrigated by: } \\
\hline Major irrigation scheme & 19.1 & 17.1 & 15.7 & 17.6 & 21.3 & 16.5 & 17.7 \\
\hline Minor irrigation scheme & 26.9 & 23.1 & 22.1 & 19.6 & 16.2 & 18.5 & 20.2 \\
\hline Well/lift irrigation & 2.0 & 1.0 & 4.6 & 4.2 & 7.8 & 6.0 & 4.8 \\
\hline Rainfed & 48.5 & 57.1 & 52.4 & 53.2 & 50.3 & 56.5 & 53.1 \\
\hline
\end{tabular}

\section{An inability to pass on higher fuel prices would result in a substantial decrease}

in income for low-income farmers. Fuel price increases were estimated to increase chemical fertilizer and spray prices by 4.0 percent. For farmers in the bottom quintile, this would result on average in an income loss equivalent to over 2.0 percent of total consumption (i.e., $0.52 * 4.0$ ). However, since food prices are now assumed to be fixed (i.e., farmers cannot pass on higher agricultural production costs), the previously estimated indirect effect arising from higher food prices is no longer incurred. For the bottom two deciles this was estimated at 0.27 percent (i.e., around 67 percent of the indirect effect of 0.4 percent). Combined with the estimated direct effect of fuel price increases for these deciles (i.e., 1.4 percent), this suggests that low-income farmers would experience approximately a 3.1 percent decrease in income from this channel alone.

\section{However, universal input subsidies would not only encourage inefficient input} use but also involve a substantial leakage of the subsidy to farmers in the highest income groups. For example, only 30 percent of fertilizer subsidies would benefit the bottom two-income quintiles. As with fuel subsidies above, a more cost-effective approach to protecting low-income farmers would be to use better-targeted direct transfers through a well-designed and implemented safety net program. Household characteristics correlated with farmer poverty could be used to target higher assistance to poor farmers. Applying an approach similar to that proposed for the reformed targeted transfer program would result in farmers from the top two quintiles receiving only 6.9 percent of the transfers compared to over 77 percent going to farmers in the bottom two quintiles. To the extent that farm productivity is a concern, this issue is best addressed by a program of extension services, which might provide knowledge of improved practices and maybe even some subsidized inputs as an incentive to participate. Such a program should be aimed at increasing the 
diffusion of efficient farming practices, is desirable even in the absence of fuel subsidy reform, and should eventually be withdrawn.

30. Subsidies to the transport sector are also often advocated to mitigate the adverse effects of fuel price increases, but universal transport subsidies are not well targeted. Table II.3 provides information on the proportion of total consumption expenditures allocated to transport expenses by income group. Since the budget shares of each transport mode increase with income, universal transport subsidies for all transport modes involve substantial leakage to higher income groups. For example, 42 percent of a universal subsidy for train and bus travel would accrue to the top two quintiles compared to 36 percent to the bottom two quintiles. It may be possible to target such subsidies better by focusing on a finer differentiation of transport modes.

\begin{tabular}{|c|c|c|c|c|c|c|c|}
\hline \multicolumn{8}{|c|}{ Table II.3. Sri Lanka: Expenditure and Subsidy Shares by Transport Mode } \\
\hline & $\begin{array}{l}\text { Bottom } \\
\text { Decile }\end{array}$ & $\begin{array}{l}\text { 2nd } \\
\text { Decile }\end{array}$ & $\begin{array}{c}\text { 2nd } \\
\text { Quintile }\end{array}$ & $\begin{array}{c}\text { 3rd } \\
\text { Quintile }\end{array}$ & $\begin{array}{c}\text { 4th } \\
\text { Quintile }\end{array}$ & $\begin{array}{c}\text { Top } \\
\text { Quintile }\end{array}$ & $\begin{array}{c}\text { All } \\
\text { Households }\end{array}$ \\
\hline \multicolumn{8}{|l|}{ Expenditure shares } \\
\hline Trains and buses & 1.4 & 1.7 & 2.0 & 2.2 & 2.3 & 1.9 & 2.0 \\
\hline Van and taxis & 0.1 & 0.2 & 0.2 & 0.3 & 0.4 & 0.7 & 0.3 \\
\hline School transport & 0.3 & 0.3 & 0.3 & 0.4 & 0.7 & 0.7 & 0.5 \\
\hline Ships and airlines & 0.0 & 0.0 & 0.0 & 0.0 & 0.0 & 0.0 & 0.0 \\
\hline Total transport & 1.9 & 2.3 & 2.8 & 3.5 & 4.8 & 7.1 & 4.1 \\
\hline \multicolumn{8}{|l|}{ Subsidy share } \\
\hline Trains and buses & 7.3 & 8.6 & 20.1 & 21.7 & 22.9 & 19.4 & 100.0 \\
\hline Van & 2.3 & 5.0 & 11.2 & 18.5 & 24.1 & 38.9 & 100.0 \\
\hline School transport & 5.4 & 5.7 & 14.3 & 18.5 & 27.9 & 28.1 & 100.0 \\
\hline Ships and airlines & 0.0 & 0.0 & 7.0 & 0.0 & 0.1 & 93.0 & 100.0 \\
\hline Total transport & 4.6 & 5.5 & 14.0 & 17.4 & 23.6 & 34.9 & 100.0 \\
\hline
\end{tabular}

\section{Concluding Remarks}

31. The results presented show that fuel subsidies are a significant drain on public funds and that the bulk of fuel subsidies accrue to higher income groups. Eliminating subsidies is clearly desirable from both a fiscal and an efficiency perspective. However, their elimination will have an adverse effect on poor households so that the desirability of subsidy reform from an equity perspective will depend on the availability of more cost-effective approaches to protecting these households. The high leakage of fuel subsidies to high-income groups suggests that it should be possible to protect poor households from the adverse effect of higher fuel prices and still generate additional budgetary savings that can be used to finance more desirable public expenditures.

32. Of the alternative mitigating measures considered, the existing Samurdhi program is the most cost effective and could be made more so by introducing improvements in its design and implementation. A reformed transfer program could 
increase both coverage of poor households as well as substantially reduce leakage of transfers to higher income households. The lack of access of poor households to electricity means that lifeline tariffs are not a cost-effective approach to compensating poor households for higher fuel prices. However, a restructuring of the tariff structure could provide protection to poor households with electricity access as well as middle-income households. Although maintaining kerosene subsidies is a more cost-effective approach to protecting poor households compared to relying on a lifeline electricity tariff and general fuel subsidies, they still involve substantial leakage to higher income households. In addition, maintaining kerosene subsidies while eliminating other fuel subsidies is likely to result in inefficient substitution from these other fuels to kerosene, with second-round revenue losses and possibly a diversion of kerosene to other uses.

\section{To the extent that it takes time and resources to introduce a reformed transfer} program, it may be desirable to retain kerosene subsidies in the short term. Some of the budgetary savings from the removal of diesel subsidies could be used to finance a reformed transfer program and additional funding from the removal of the kerosene subsidy in the medium term could be made conditional on evidence that the program has improved its cost effectiveness. A cost-effective transfer program will also provide a basis for promoting structural reforms more generally.

\section{Although higher agricultural production costs and transport costs are a major} factor behind lower incomes for low-income households, universal input and transport subsidies would involve substantial leakage to high-income households and reduce incentives for consumers to respond efficiently to higher prices. A reformed transfer program would provide a more cost-effective approach to social protection. Finer targeting of specific sectoral measures, including targeting extension services to farmers or subsidizing transport modes that are used primarily by low and middle-income households, could also be considered. 


\section{References}

Amarasinghe, D., and S. B. Jayatilleke, 2005, "Input-Output Tables for Sri Lanka, 2000," Macroeconomic Policy Series No. 16 (Colombo, Sri Lanka: Institute of Policy Studies).

Department of Census and Statistics, 2002, Household Expenditure and Income Survey 2002, Final Report (Colombo, Sri Lanka).

Munasinghe Institute of Development, 2004, "Impact of Power Sector Policy and Regulation in Sri Lanka with Emphasis on Poor Consumers” (Colombo, Sri Lanka).

Narayan, A., T. Vishwanath, and N. Yoshida, 2006, "Sri Lanka: Welfare Reform," in Poverty and Social Impact Analysis of Reforms, eds. by A. Coudouel, A. Dani, and S. Paternostro (Washington: World Bank). , and Nobuo Yoshida, 2005, "Proxy Means Test for Targeting Welfare Benefits in Sri Lanka," SASPR Working Paper 33258 (Washington: World Bank, Poverty Reduction Group and Social Development Department)

World Bank, 2005, Poverty and Social Impact Analysis for Sri Lanka: An Analysis of the Impact of Welfare Reform (Washington: World Bank, Poverty Reduction Group and Social Development Department). , 1999, Sri Lanka Integrated Survey (Washington). 


\section{Are Workers' Remittances A Hedge Against Shocks? The CASE OF SRI LANKA ${ }^{12}$}

\section{A. Introduction}

\section{Despite Sri Lanka's astonishing resilience, the country remains vulnerable to} external shocks. With an average growth rate of 5 percent during the 1990s and 6-7 percent recently, Sri Lanka's growth performance is remarkable. Nevertheless, the country's export base is narrow, with garment and tea exports accounting for two thirds of merchandize exports, and the expiration of the Multifiber Agreement in 2005 has added to competitive pressures. Tourism, another major exchange earner, has recovered from the tsunami but faces new threats from a deteriorating security situation. Finally, the country's heavy reliance on oil, particularly in energy generation, exposes it more than others to movements in world prices. Between 2003 and 2005 Sri Lanka's oil balance deteriorated by 2.4 percentage points of GDP, compared to 1.7 percentage points of GDP for the average low-income country in Asia.

2. On the other hand, Sri Lanka has access to a large and relatively stable source of foreign exchange-workers' remittances. Over the last two decades, workers' remittances have increased by an annual average of 10 percent and since 1994 constitute the largest source of foreign financing for the island (8.3 percent of GDP in 2005). Some 4 percent of the Sri Lankan population work abroad, mostly in the oil rich Gulf states, making Sri Lanka one of the leading recipients of remittances as a share of GDP. Remittances are a particularly attractive source of foreign financing, because they are much more stable over time than private capital flows. In addition, they are unrequited transfers, which unlike other capital flows, do not create obligations in the future.

\section{This paper explores to what extent, workers' remittances have helped cushion} Sri Lanka against economic shocks and are likely to do so in the future. It is widely believed that workers' remittances are to a great extent motivated by altruism. ${ }^{13}$ Under this assumption, they should be negatively correlated with income in the home country and as such constitute an insurance against shocks. Similarly, they should be positively correlated with incomes and wages in the host countries - in this case the Gulf States - and, hence, provide a welcome hedge against rising oil prices. Alternatively, remittances could be motivated by investment considerations, in which case they should respond to interest rate differentials and, in general, be more aligned with the business cycle in the home country. Under either hypothesis, other macroeconomic variables are likely to have a bearing on the

\footnotetext{
${ }^{12}$ Prepared by Erik Lueth and Marta Ruiz-Arranz.

${ }^{13}$ See Lucas and Stark (1985) and Rapoport and Docquier (2005).
} 
amount of money sent home, notably the exchange rate and the price level in the home country.

4. A better understanding of what determines remittances, and in particular their cyclical properties, could help assess the potential role of remittances as a shock absorber. The central question is whether remittance receipts respond to economic conditions in the home country. A few studies investigate the cyclicality of inward remittances. IMF (2005) reports the correlation between detrended global remittances and detrended world GDP and finds that remittances are procyclical, albeit to a lesser extent than official aid, exports, and portfolio investment. Using the same approach on a country-bycountry basis, Giuliano and Ruiz-Arranz (2005) show that remitting patterns vary across countries with procyclical remittances observed in two thirds of developing countries, suggesting that investment considerations play an important role. More recently, in a related cross-country work, we estimate a gravity model of bilateral remittance flows for a limited number of developing countries and find that remittances are aligned with the business cycle in the home country. These results suggest that remittances can play some role, but perhaps not a major one, in limiting vulnerability to shocks. Being procyclical, remittances tend to falter when exports weaken and GDP growth slows. They also decline when the home investment and political climate worsens and do not seem to respond to adverse shocks at home. $^{14}$

5. Most studies of the macroeconomic determinants of remittances have focused on one country only whose diaspora is concentrated in a known country, or small group of countries. Straubhaar (1986) finds that wages and employment in Germany have a positive impact on Turkish inward remittances. El Sakka and McNabb (1999) try to explain nominal remittances received by Egypt and find that remittances increase with Egyptian inflation and income abroad and decline with the black market premium. For India, Gupta (2005) regresses real inward remittances on oil prices and migrants' real overseas earnings and finds the latter to enter significantly and positive. In a second class of regressions, she finds that changes in U.S. employment and an Indian drought dummy have a positive impact on the cyclical component of remittances. Bouhga-Hagbe (2004) uses a vector error correction (VEC) specification to model workers' remittances received by Morocco. The cointegration vector suggests that, over the long run, inward remittances are positively correlated with French wages and negatively correlated with real GDP in Morocco.

6. These attempts to establish a relationship between workers' remittances and a set of macroeconomic variables suffer from a number of shortcomings. Some studies fail to discuss and account for the time series properties of the variables under investigation, although regressions of nonstationary variables are known to be spurious. One study runs a

\footnotetext{
${ }^{14}$ See Lueth and Ruiz-Arranz (2006).
} 
regression in variations - supposedly removing any nonstationarity — but fails to test for co-integration, thus opening the door for omitted variable bias. Moreover, some of the macroeconomic variables, such as the exchange rate, the price level or GDP, could be affected by remittances on top of affecting remittances. However, most studies ignore issues of endogeneity and reverse causality. Bougha-Hagbe (2004) is the noteworthy exception in accounting for time series properties and endogeneity, but robustness of his findings are questionable given that a VEC model with 22 parameters is estimated using 35 observations.

7. Our analysis tries to overcome weaknesses in previous studies and shows that remittances to Sri Lanka may be less of a hedge against shocks than commonly believed. We estimate a Vector Error Correction (VEC) model for Sri Lanka remittance receipts using quarterly data from 1996 to 2004. Our main focus lies on the response of remittances to a number of macroeconomic variables, namely real GDP, CPI, exchange rate, interest rate, and oil price. We find that remittances are positively correlated with the oil price, but behave strongly procyclical, and decline when the Sri Lankan currency weakens.

\section{B. Stylized Facts}

\section{Workers' remittances in Sri Lanka increased at an average annual rate of} 10 percent over the last 20 years and since the mid-1990s constitute the largest source of foreign financing. In 2005, workers' remittances amounted to 8.3 percent of GDP, compared to 2.5 percent of GDP in official development assistance (ODA), 1 percent of GDP in FDI, and $1 / 2$ percent of GDP in portfolio investment. Sri Lanka's prime export, textile and garments, amounted to 12 percent of GDP (Figure III.1).

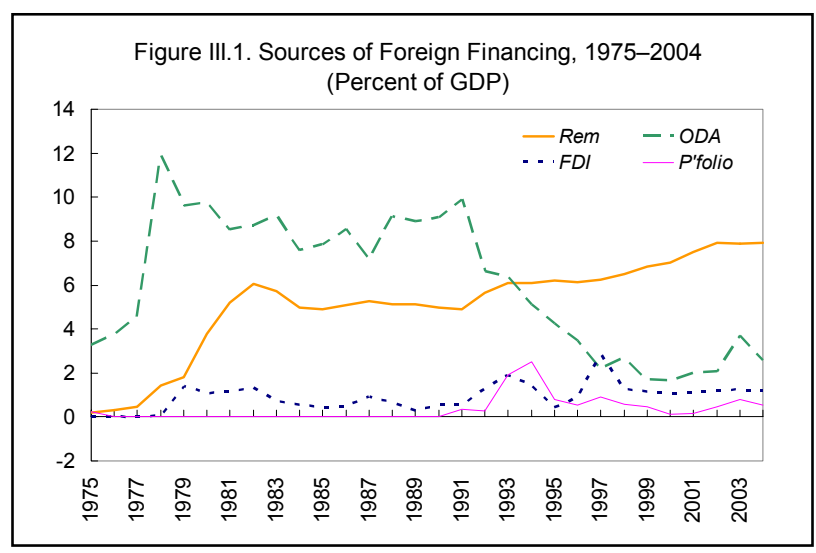

9. The evolution of Sri Lanka's inward remittances is broadly in line with the trend observed in global remittance flows. As a global aggregate, workers' remittances have become the largest source of foreign financing after FDI, exceeding both official development assistance and portfolio investment by a wide margin. In 2005, remittances to developing countries amounted to $\$ 165$ billion. Asia and the Pacific is the main destination region for remittances, accounting for 45 percent of the global total. Some of the surge in workers' remittances may be attributable to better recording and a shift from informal to formal channels, particularly after September 11, 2001. However, underpinned by mounting demographic pressures in the developing world, remittance flows are unlikely to abate soon. In the case of Sri Lanka, persistent rural poverty, growing inequality, and ethnic tensions will continue to secure stable flows of remittances in the medium term. 
10. Inward remittances are large relative to the size of the Sri Lankan economy. Among 13 developing countries of broadly equal size, Sri Lanka exhibits the fourth largest remittances-to-GDP ratio (Figure III.2). In Asia, Sri Lanka is surpassed only by the Philippines (13.7 percent of GDP), Mongolia (13.3 percent of GDP), and Nepal (12.9 percent of GDP).

11. Inward remittances are sensitive to swings in oil prices, as close to 85 percent of Sri Lankan migrants reside in countries which are net oil exporters. According to the Sri Lanka Bureau of Foreign Employment (2004), the number of overseas workers amounted to 744,100 in 2004 , or 3.8 percent of the population. These workers are concentrated in a few countries with Saudi Arabia, Kuwait, United Arab Emirates, and Qatar hosting 80 percent.

\section{Sri Lanka remittances are less volatile than private capital flows and ODA,} confirming a pattern observed for global aggregates. The standard deviation of remittances amounts to 43 percent of the mean, compared with 51 percent for ODA, 68 percent of FDI and 164 percent for portfolio investment. Merchandise exports, on the other hand, are less volatile than remittances, deviating only 21 percent from the mean.

\section{Remittances to Sri Lanka seem to be procyclical and, strikingly, more so than} any other source of foreign exchange. Remittances and GDP, when detrended by the Hodrick-Prescott filter, show a correlation of almost 70 percent over the period 1975-2004; slightly higher than the correlation of exports and GDP. Private capital flows and GDP are positively correlated at only 20 percent, while ODA is counter-cyclical. Figure III.3 plots remittance receipts against a couple of macroeconomic aggregates. The procyclicality of remittances is borne out by the first figure, which plots the log-differences of Sri Lanka remittance receipts and GDP over 1985-2005. Since the mid-1990s remittances and GDP seem to be moving in log-step. Noteworthy also the year 2001, when Sri Lanka was hit by a number of severe shocks, including a military attack on the Colombo airport, disruptions of the power supply, and severe weather. GDP contracted for the first time in 50 years and remittances recorded the lowest growth in more than 10 years. Similar responses of remittances to dramatic changes in the home country's economic conditions have been observed for other countries (World Bank, 2003). In the Philippines, remittances rose steadily throughout the early 1990s, but became more volatile with the financial crisis in the late 1990s. In Turkey, remittance receipts increased for most of the 1990s, but started to decline when the crisis hit in 1999 and 2000. 
Figure III.2. Sri Lanka: Stylized Facts About Remittances

Workers Remittances for Selected Countries 1/

Overseas Workers by Host Countries, 2004 (Percent of GDP)

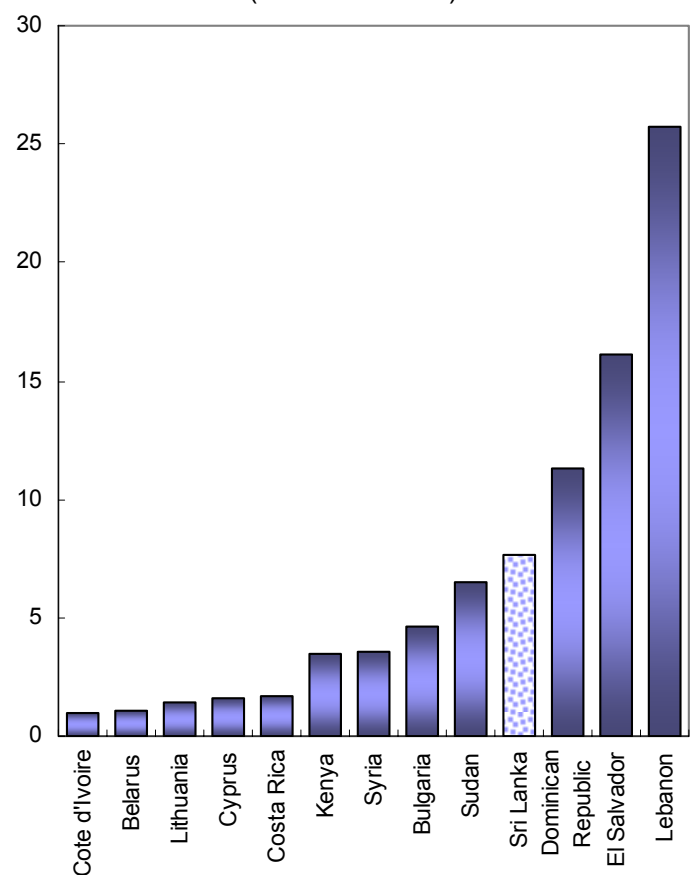

Source: IMF, Balance of Payment Statistics Yearbook.

1/ Latest years. Countries have similar GDP in U.S. dollar terms.

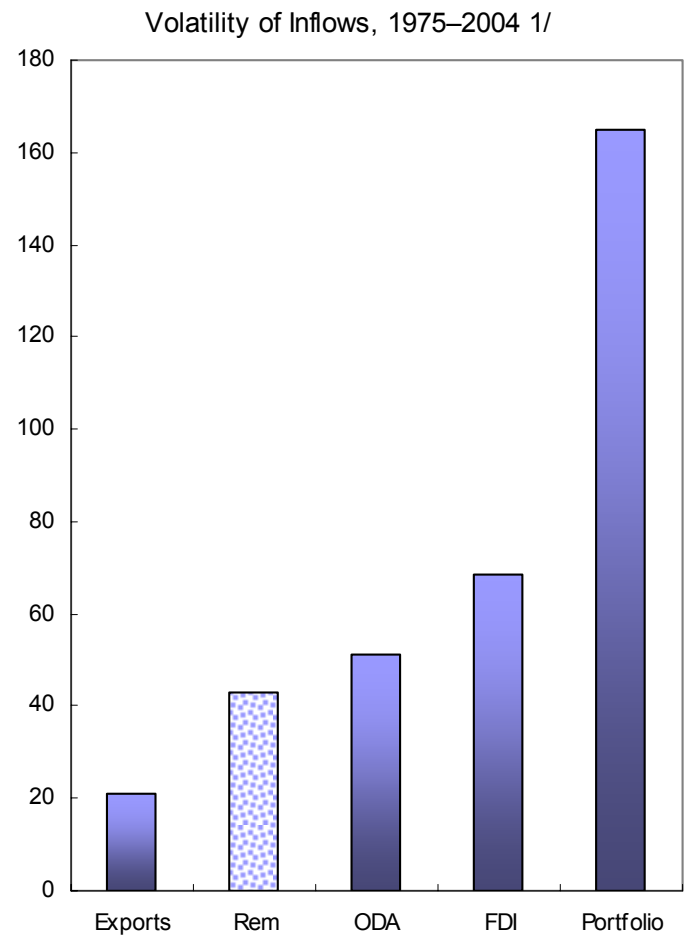

Source: IMF, Balance of Payments Statistics Yearbook.

$1 /$ Volatility is expressed in standard deviation as percent of the mean.

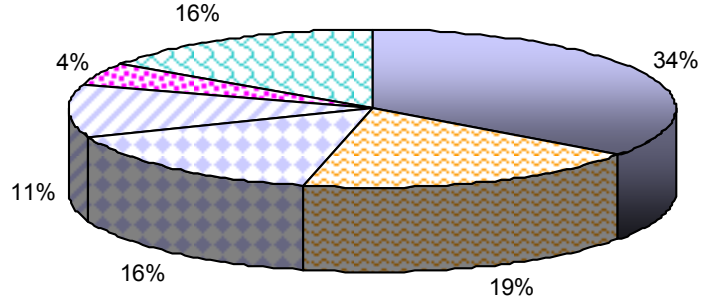

Source: Sri Lanka Bureau of Foreign Employment, 2004.

Cyclicality of Inflows, 1975-2004 1/

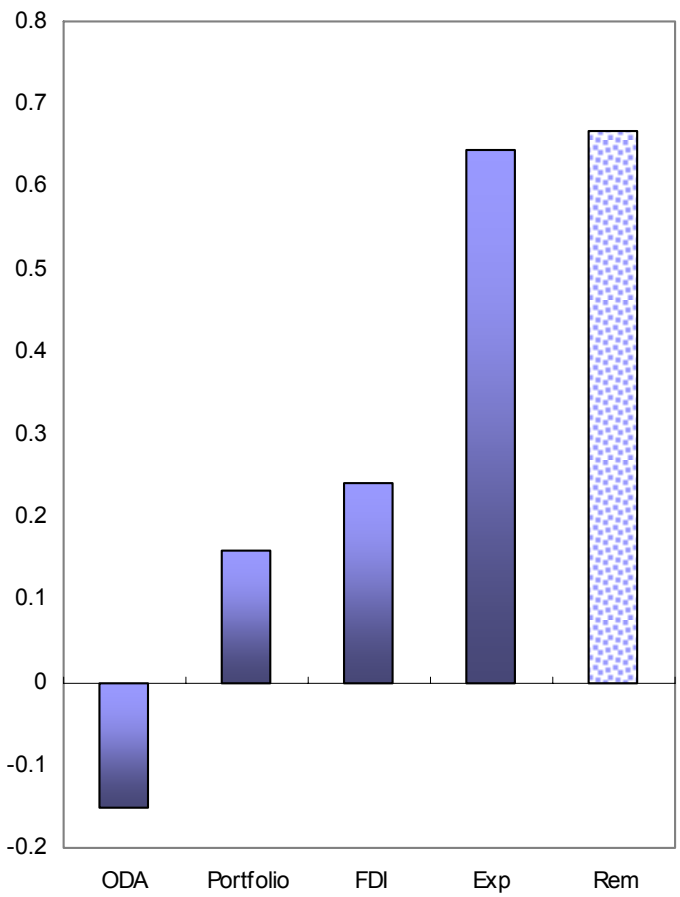

Source: IMF, Balance of Payments Statistics Yearbook.

$1 /$ Cyclicality is defined as the correlation betw een the inflow and GDP, both detrended. 
Figure III.3. Sri Lanka: Correlations of Remittances and Macroeconomic Variables

Remittances and Real GDP, 1985-2004 (In log differences)

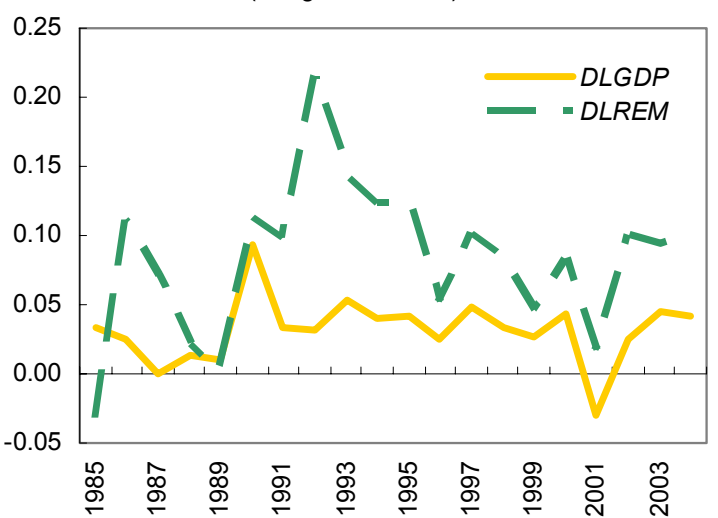

Sources: IMF, Balance of Payments Statistics Yearbook, and WEO database.

Remittances and Oil Price, 1985-2004 (In log differences)

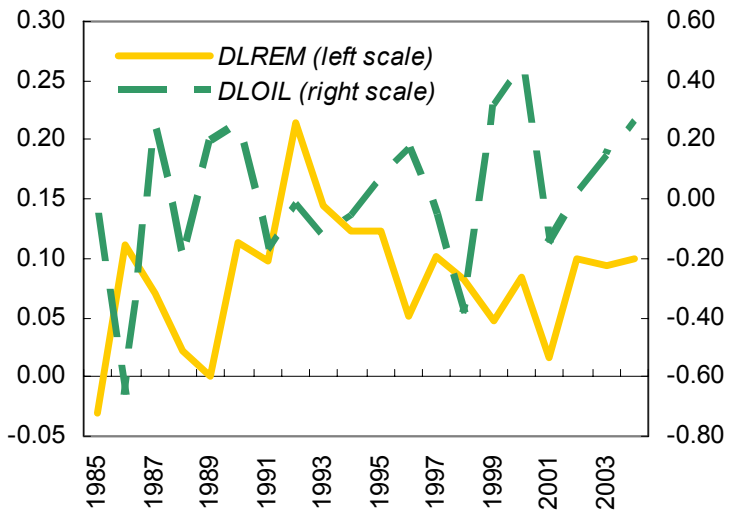

Sources: IMF, Balance of Payments Statistics Yearbook, and International Financial Statistics Yearbook.

Remittances and Interest Rate Differential, 1985-2004 1/ (In log differences)

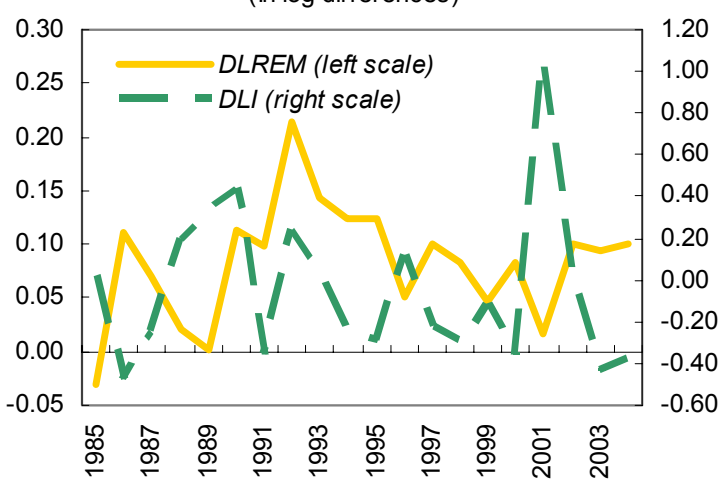

So urces: IM F, Balance of Payments Statistics Yearbook , and International Financial Statistics Yearbook ; World Bank, World Development Indicators $\checkmark$ Interest differential between the 3-month deposit rate in Sri Lanka and the 3month LIBOR.
Remittances and the Exchange Rate, 1985-2004

(Sri Lankan rupee/U.S. dollar, in log differences)

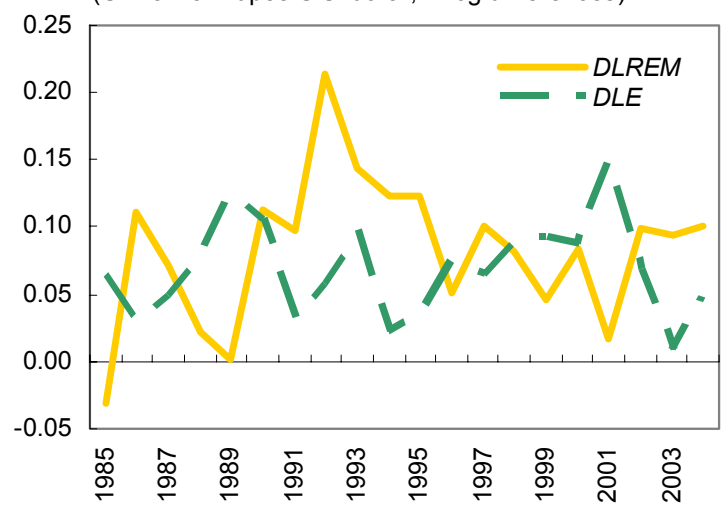

Sources: IMF, Balance of Payments Statistics Yearbook, and International Financial Statistics Yearbook.

Remittance and Real GDP Per Capita in the Gulf, 1985-2004 1/ (In log differences)

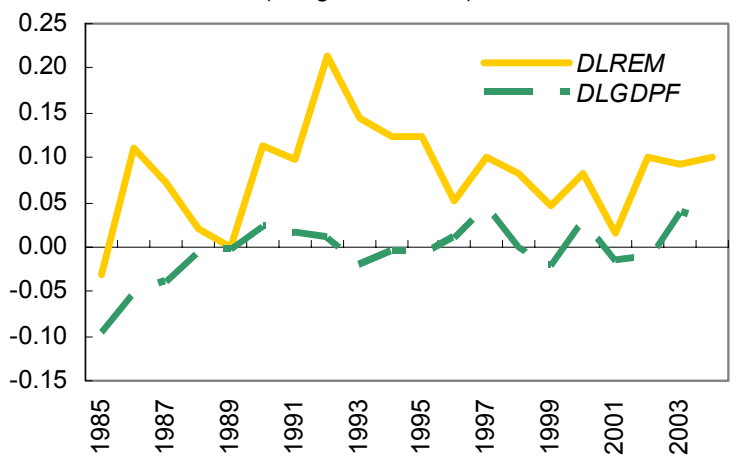

Sources: IM F, Balance of Payments Statistics Yearbook , and International Financial Statistics Yearbook ; World Bank, World Development Indicators $\checkmark$ A verage real GDP per capita of Saudi Arabia, Kuwait, United Arab Emirates, Qatar, B ahrain, and Oman weighted by stock of Sri Lankan residents in 2004.

Remittances and CPI, 1985-2004 (In log differences)

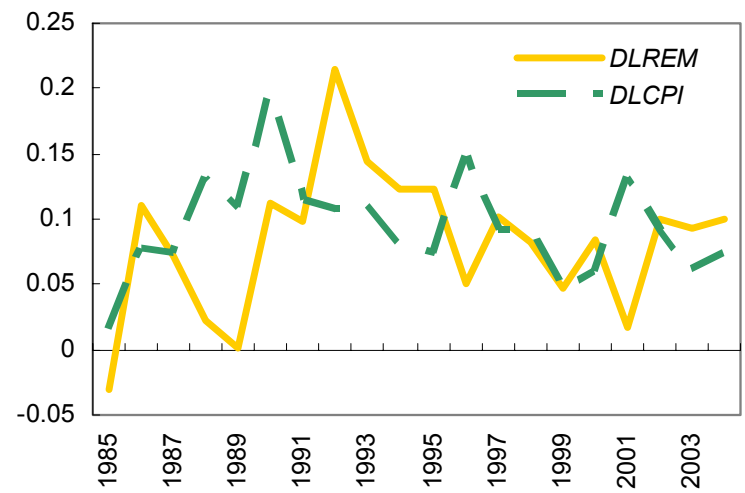

Sources: IMF, Balance of Payments Statistics Yearbook, and International Financial Statistics Yearbook. 
14. Since the mid-1990s, one also observes a strong positive correlation between remittance receipts and GDP of the workers' host countries. But, although Sri Lankans seek employment mostly in oil exporting countries, the correlation with oil prices is less clear-cut. Moreover, remittances appear to be negatively correlated with the exchange rate (implying less remittances when the currency weakens) and the interest rate (if at all), but not correlated with the price level.

\section{Econometric Analysis}

15. We estimate a VEC model for Sri Lanka to determine the response of remittance receipts to shocks in macroeconomic variables. The choice of a VEC model was based on the following considerations:

- Most of the macroeconomic variables are endogenous, suggesting a multi-equation estimation. Many of the macroeconomic variables are likely to affect remittances but, given the magnitude of remittances, are also likely to be affected by remittances. Giuliano and Ruiz-Arranz (2005) provide evidence that remittances boost GDP by easing liquidity constraints. Large remittance flows may also lead to Dutch disease phenomena, that is nominal currency appreciation or inflation (or both). In fact, anecdotal evidence points to a link between large remittance inflows and house price inflation in some Latin American countries. Moreover, some of the macroeconomic variables, such as interest rates, exchange rates, and CPI are likely to be correlated among themselves. To account for these interactions without imposing too many restrictions we opt for a Vector Auto Regression (VAR).

- Many of the variables are nonstationary, suggesting an estimation in first (or higher) differences. If nonstationary time series are regressed upon each other, the resulting t-statistics are biased upward, implying a correlation between variables, when in fact there is none. Differencing the time series until they become stationary is the usual way out. We, therefore, estimate a VAR in first differences.

- The variables may be cointegrated, suggesting the inclusion of the cointegration relationship as an additional regressor. Estimating a simple VAR in differences, when the variables are cointegrated - that is a linear combination of the variables in levels is stationary - introduces omitted variable bias. In effect, one ignores important information about the variables' long-term relationship. We therefore estimate a VEC model, a VAR in first differences that includes the long-term relationship of the endogenous variables as an additional regressor. 
16. Our dataset covers the period 1996-2004 on a quarterly basis. ${ }^{15}$ While annual remittance data is available back to 1975 , such a series would contain fewer observations and is more likely to contain structural breaks. As potential shock variables the dataset includes what the literature usually refers to as macroeconomic determinants of remittances, namely real GDP and CPI in the receiving country, the exchange rate, and a relative rate of return. Another common determinant, real GDP in the host country, is not available on a quarterly basis for the Gulf States. It is proxied by the world oil price, which is of more immediate interest for this study.

\section{The data used in the analysis are drawn from the IMF databases and the} country's national statistics. Remittance (REM) data, in millions of U.S. dollar, is taken from the IMF Balance of Payments Statistics Yearbook and comprises the line items workers' remittances, compensation of employees, and migrant capital transfers. Real GDP (GDP), in billions of rupees and at 1996 prices, is taken from the WEO database. The relative rate of return (I), in percentage points, is calculated as the difference between Sri Lanka's interest rate on 3-months fixed deposits and the LIBOR on 3-months dollar deposits. Data on interest rates, the Colombo consumer price index (CPI), the rupee/dollar exchange rate $(\mathrm{E})$ and the oil price (OIL) - a simple average of UK Brent, Dubai, and West Texas crude prices - all stem from the International Financial Statistics Yearbook. Data are in levels and not seasonally adjusted.

\section{We first test for the presence of unit roots in the macroeconomic time series} using the augmented Dickey Fuller test and find that all series are integrated of order one. To determine the appropriate lag length we start with a large number of lags and subsequently eliminate lags with insignificant coefficients. The choice of model, that is whether to include an intercept or time trend, is based on the approach of Doldado and others (1990). Under this approach, one starts with the least restrictive of plausible models and then introduces restrictions until the null hypothesis of a unit root is rejected (if at all). As shown in Table III.1, the data series are found to be nonstationary in levels (have unit roots) and stationary in first differences. Hence, all series are integrated of order one.

\begin{tabular}{|c|c|c|c|c|c|c|}
\hline \multicolumn{7}{|c|}{$\begin{array}{l}\text { Table III.1. Sri Lanka: Augmented Dickey Fuller Test for Non-Stationarity 1/ } \\
\text { (Sample: 1995Q1-2004Q4) }\end{array}$} \\
\hline & \multicolumn{3}{|c|}{ Level } & \multicolumn{3}{|c|}{ First Difference } \\
\hline & t-ADF & Lags & Model 2/ & t-ADF & Lags & Model 2/ \\
\hline Remittances & 1.28 & 3 & 2 & $-5.34^{* * *}$ & 2 & 3 \\
\hline Real GDP & 1.16 & 3 & 2 & $-13.28^{* * *}$ & 1 & 3 \\
\hline $\mathrm{CPI}$ & 0.84 & 0 & 2 & $-2.91 * * *$ & 0 & 3 \\
\hline Exchange rate & -0.25 & 1 & 2 & $-4.43^{* * *}$ & 0 & 2 \\
\hline Interest differential & -1.13 & 1 & 3 & $-2.66^{* * *}$ & 0 & 3 \\
\hline Oil price & 1.57 & 0 & 3 & $-4.68^{* * *}$ & 0 & 3 \\
\hline \multicolumn{7}{|c|}{$\begin{array}{l}1 /{ }^{* * *} \text { denote rejection at the } 1 \text { percent level. } \\
2 / \text { Model } 1 \text { includes trend and intercept; Model } 2 \text { includes intercept, but no trend; and Model } \\
3 \text { includes neither. }\end{array}$} \\
\hline
\end{tabular}

\footnotetext{
${ }^{15}$ Given the data coverage, the analysis does not capture the impact of the tsunami on remittance flows.
} 
19. Next, we test for the existence of a cointegration vector following Johansen (1991) and find one cointegration relationship.

The vector auto regression includes two lags as suggested by the LR test statistic and most other selection criteria. As shown in Table III.2, the trace statistic indicates the existence of at most 3 cointegration vectors, while the eigenvalue statistic

\begin{tabular}{|c|c|c|c|}
\hline \multicolumn{4}{|c|}{$\begin{array}{l}\text { Table III.2. Sri Lanka: Cointegration Test } \\
\text { for REM, GDP, CPI, E, I, OIL 1/ }\end{array}$} \\
\hline $\begin{array}{l}\text { Hypothesized Number of } \\
\text { Cointegration Vector(s) }\end{array}$ & Eigenvalue & $\begin{array}{l}\text { Trace } \\
\text { Statistic }\end{array}$ & $\begin{array}{l}\text { Maximum } \\
\text { Eigenvalue } \\
\text { Statistic }\end{array}$ \\
\hline None & 0.81 & $143.23^{* * *}$ & $58.87^{* * *}$ \\
\hline At most 1 & 0.61 & $84.36^{* * *}$ & 33.45 \\
\hline At most 2 & 0.49 & 50.90 ** & 24.27 \\
\hline At most 3 & 0.43 & 26.63 & 20.20 \\
\hline \multicolumn{4}{|c|}{$\begin{array}{l}1 / \text { Rejection at the } 1,5 \text {, and } 10 \text { percent level denoted by }{ }^{* * *},{ }^{* *} \text {, and *, } \\
\text { respectively. }\end{array}$} \\
\hline
\end{tabular}
confirms the existence of at most 1 cointegration vector. Over the long run, remittances move with the other macroeconomic variables based on the following cointegrating relationship (t-statistic in parenthesis):

$$
\begin{gathered}
\mathrm{REM}=-434.13-1.03 * \mathrm{OIL}+3.82 * \mathrm{I}+4.05 * \mathrm{GDP}-2.78 * \mathrm{E}+1.05 * \mathrm{CPI} \\
(2.82) \quad(2.51) \quad(10.04)
\end{gathered}
$$

20. The estimation of the VEC model and the impulse response functions confirm the evidence presented in Section $B$, namely that remittances are procyclical and increase with oil prices. The estimates of the VEC model are presented in Appendix III.1. The impulse response functions illustrate how one standard deviation shocks in the oil price, the exchange rate, GDP, the interest rate, and CPI affect remittances (Figure III.4).

- Remittances are procyclical: remittances increase when economic activity in the home country accelerates and they decrease when economic conditions deteriorate, an indication that investment considerations are at play. In particular, an increase in real GDP by 5.5 billion of 1996 rupees ( 2 percent) leads to an increase in remittances by $\$ 30$ million ( 2 percent). This suggests that remittances respond to investment opportunities and the business and political climates in the home country as much as to altruistic and insurance considerations. It also implies that remittance flows may not be as important to smooth fluctuations or shocks in the economy as commonly believed.

- $\quad$ Remittances fall when the exchange rate weakens: a one percent depreciation of the rupee against the dollar leads to a $\$ 15$ million reduction in remittances (1 percent) in the first year and another $\$ 5$ million reduction thereafter. Depreciation of the rupee reduces remittances as migrants may need to send less dollars in order to buy the same goods basket at home as before the depreciation. 
Figure III.4. Sri Lanka: Impulse Response Functions
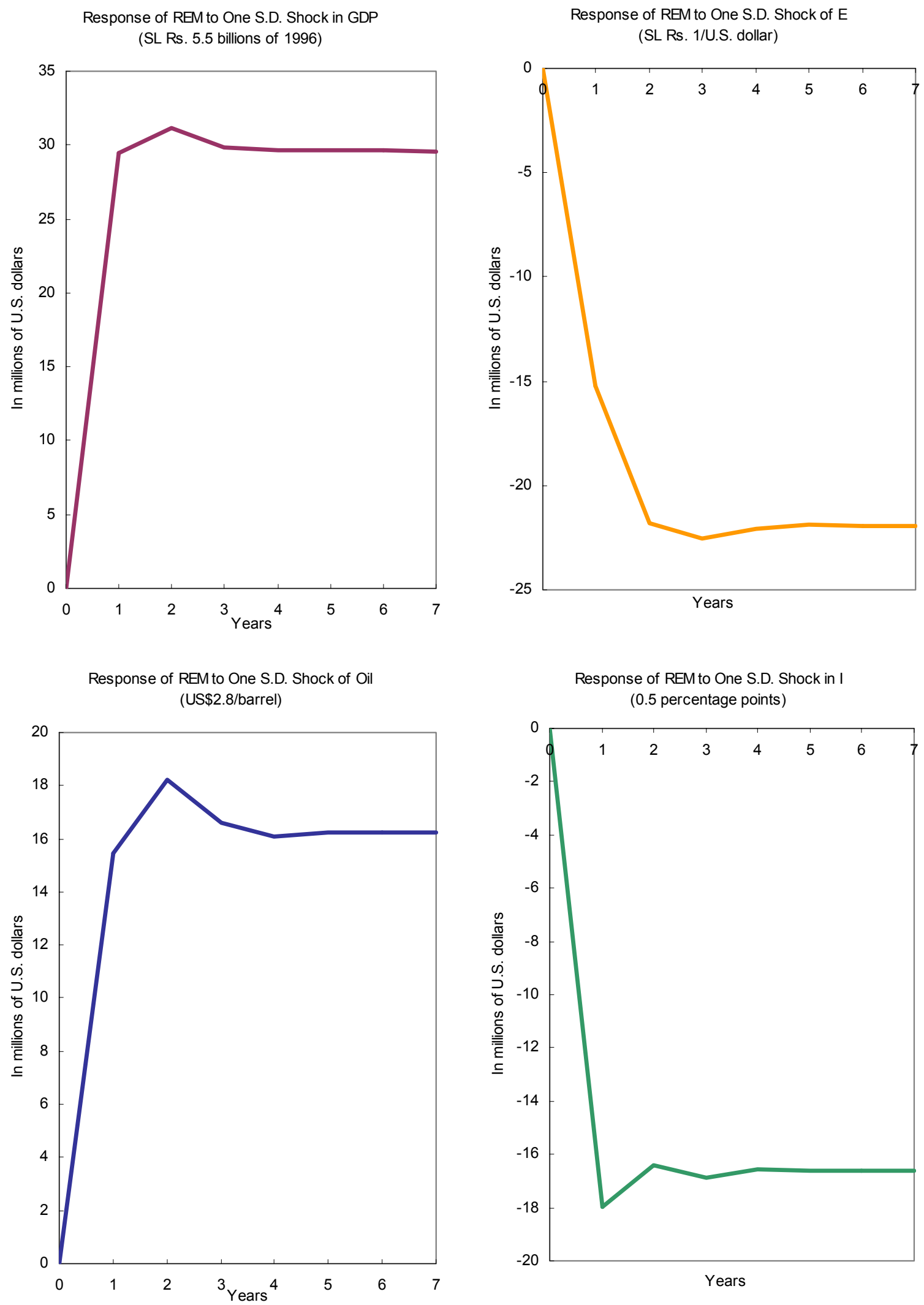
- $\quad$ Remittances increase with oil prices: an oil price increase of $\$ 2.8$ per barrel is associated with a $\$ 15$ million increase in remittances (1 percent). In the case of Sri Lanka, oil prices may be a good proxy for the economic activity in its migrants' host countries. This result suggests that greater economic activity in the host country increases the chances of employment and wages, allowing migrants to send more remittances.

- $\quad$ Remittances fall with higher interest rates: an increase in interest rates in Sri Lanka (vis-à-vis LIBOR) by $1 / 2$ percentage point results in an $\$ 18$ million reduction inremittances. ${ }^{16}$ The result that interest rate differentials are not important in attracting remittances is in line with earlier research and could explain the relative stability of remittances when compared with other types of capital flows. This finding together with that regarding the positive association of remittances with GDP growth suggests that remittances do not seem to respond to investment in interest bearing assets (i.e., financial investment) but they respond to productive investment opportunities.

- Inflation does not seem to have any significant effect on remittances: CPI shocks do not trigger any change in remittance flows. This result is in contrast with our related cross-country work that finds that higher inflation in the home country encourage remittances to compensate for the loss of purchasing power at home.

21. Our main findings are robust to other specifications. We reduce the lag length from 2 to 1 , to decrease the number of estimated parameters from 14 to 8 . The cointegration relationship stays broadly the same. The impulse response functions are qualitatively the same and quantitatively very similar, except for I which has less of an impact. Estimating bivariate correlations, we find that REM are cointegrated with GDP, E, and I. The impulse response functions are qualitatively the same, but the impact of the exchange rate is larger and the impact of GDP and I is smaller in the bivariate setting. Finally, we estimate a VEC model in REM, GDP, E, and I, the variables that are found to be correlated with REM on a bivariate basis. Cointegration equation and impulse response functions are qualitatively the same as in the baseline specification, and quantitatively very similar.

\section{Conclusion}

\section{Remittance receipts seem to be procyclical in Sri Lanka, undermining their usefulness as a shock absorber upon deterioration in economic fundamentals. This paper}

\footnotetext{
${ }^{16}$ While remittances increase in interest rates according to the cointegration relationship, this only holds under the ceteris paribus assumption. The VEC model implies that all variables are interdependent, and so a positive shock to the interest rate depresses GDP, which in turn depresses remittances - an effect that dominates the direct impact of interest rate on remittances.
} 
explores to what extent Sri Lanka's large receipts of workers' remittances serve as a hedge against macroeconomic shocks. Both descriptive evidence and econometric analysis show that workers' remittances are positively correlated with real GDP but negatively correlated with the strength of the rupee exchange rate and interest rate differentials, limiting their potential as shock absorber.

23. However, remittances are positively correlated with oil prices, offering a hedge against oil shocks. This is particularly important in Sri Lanka with a large percent of its migrant population working in the oil rich Gulf States and with oil imports accounting for more than 20 percent of total imports. During the most recent oil shock, robust growth in remittance flows has contributed to finance the current account, strengthen the balance of payments and accumulate reserves.

\section{The evidence about what motivates remittances is mixed, but altruism may be} less of a factor in Sri Lanka than commonly believed. The procyclicality of remittances calls into question the notion that remittances are largely motivated by altruism. At the same time we fail to confirm portfolio considerations as a prime motive, since no positive link is established between remittances and relative rates of return. This result is in line with our cross-country research paper that applies a gravity model to explain bilateral remittance flows. We find a positive association between remittance receipts and the dependency ratio in the home country, suggesting that helping those at home is an important motive. However, remittances appear to be procyclical, suggesting an investment motive. Remittances are also sensitive to the investment and political climate in the home and host countries, again suggesting that (non-financial) investment considerations play an important role.

\section{The results suggest that while remittances should be encouraged they should not} be seen as a panacea. Remittances can yield important economic benefits to Sri Lanka, providing financing and supporting consumption and investment. They can also play an important role in the regional development of the country and in reducing vulnerability to oil shocks. On the other hand, they may be of limited value in absorbing shocks to macroeconomic fundamentals (GDP and exchange rate). While it is important to continue facilitating remittance inflows with policies directed at reducing transaction costs, promoting financial sector development, and improving the business climate, remittances should not be seen as a substitute for government policy and structural reform. 
Appendix III.1. Vector Error Correction Estimates 1/

\begin{tabular}{|c|c|c|c|c|c|c|}
\hline Error Correction & $\mathrm{D}(\mathrm{REM})$ & $\mathrm{D}(\mathrm{OIL})$ & $\mathrm{D}(\mathrm{I})$ & $\mathrm{D}(\mathrm{GDP})$ & $D(E)$ & $\mathrm{D}(\mathrm{CPI})$ \\
\hline CointEq1 & $\begin{array}{l}-0.730 \\
(0.358)\end{array}$ & $\begin{array}{l}-0.012 \\
(0.043)\end{array}$ & $\begin{array}{l}-0.002 \\
(0.008)\end{array}$ & $\begin{array}{r}0.446 \\
(0.088)\end{array}$ & $\begin{array}{r}0.015 \\
(0.017)\end{array}$ & $\begin{array}{l}-0.011 \\
(0.032)\end{array}$ \\
\hline $\mathrm{D}(\mathrm{REM}(-1))$ & $\begin{array}{l}-0.317 \\
(0.304)\end{array}$ & $\begin{array}{l}-0.006 \\
(0.037)\end{array}$ & $\begin{array}{l}-0.003 \\
(0.007)\end{array}$ & $\begin{array}{l}-0.369 \\
(0.075)\end{array}$ & $\begin{array}{r}-0.028 \\
(0.014)\end{array}$ & $\begin{array}{r}0.046 \\
(0.027)\end{array}$ \\
\hline $\mathrm{D}(\mathrm{REM}(-2))$ & $\begin{array}{l}-0.101 \\
(0.219)\end{array}$ & $\begin{array}{r}0.014 \\
(0.027)\end{array}$ & $\begin{array}{l}-0.003 \\
(0.005)\end{array}$ & $\begin{array}{l}-0.212 \\
(0.054)\end{array}$ & $\begin{array}{r}-0.018 \\
(0.010)\end{array}$ & $\begin{array}{r}0.025 \\
(0.020)\end{array}$ \\
\hline $\mathrm{D}(\mathrm{OIL}(-1))$ & $\begin{array}{r}0.736 \\
(1.784)\end{array}$ & $\begin{array}{r}0.236 \\
(0.216)\end{array}$ & $\begin{array}{l}-0.014 \\
(0.042)\end{array}$ & $\begin{array}{l}-0.365 \\
(0.438)\end{array}$ & $\begin{array}{r}-0.047 \\
(0.085)\end{array}$ & $\begin{array}{l}-0.077 \\
(0.160)\end{array}$ \\
\hline $\mathrm{D}(\mathrm{OIL}(-2))$ & $\begin{array}{r}1.649 \\
(1.709)\end{array}$ & $\begin{array}{r}0.138 \\
(0.207)\end{array}$ & $\begin{array}{r}0.024 \\
(0.040)\end{array}$ & $\begin{array}{r}0.232 \\
(0.419)\end{array}$ & $\begin{array}{r}0.102 \\
(0.081)\end{array}$ & $\begin{array}{r}0.058 \\
(0.154)\end{array}$ \\
\hline $\mathrm{D}(\mathrm{I}(-1))$ & $\begin{array}{r}-8.007 \\
(11.132)\end{array}$ & $\begin{array}{l}-0.796 \\
(1.347)\end{array}$ & $\begin{array}{r}0.555 \\
(0.261)\end{array}$ & $\begin{array}{r}-3.419 \\
(2.731)\end{array}$ & $\begin{array}{r}0.479 \\
(0.528)\end{array}$ & $\begin{array}{r}-1.030 \\
(1.001)\end{array}$ \\
\hline $\mathrm{D}(\mathrm{I}(-2))$ & $\begin{array}{r}3.586 \\
(9.913)\end{array}$ & $\begin{array}{r}1.122 \\
(1.199)\end{array}$ & $\begin{array}{l}-0.160 \\
(0.233)\end{array}$ & $\begin{array}{l}-1.498 \\
(2.432)\end{array}$ & $\begin{array}{r}-0.433 \\
(0.470)\end{array}$ & $\begin{array}{r}1.143 \\
(0.891)\end{array}$ \\
\hline $\mathrm{D}(\mathrm{GDP}(-1))$ & $\begin{array}{l}-0.750 \\
(0.825)\end{array}$ & $\begin{array}{l}-0.046 \\
(0.100)\end{array}$ & $\begin{array}{l}-0.005 \\
(0.019)\end{array}$ & $\begin{array}{r}0.813 \\
(0.203)\end{array}$ & $\begin{array}{r}0.018 \\
(0.039)\end{array}$ & $\begin{array}{r}0.046 \\
(0.074)\end{array}$ \\
\hline $\mathrm{D}(\mathrm{GDP}(-2))$ & $\begin{array}{l}-1.014 \\
(0.811)\end{array}$ & $\begin{array}{l}-0.062 \\
(0.098)\end{array}$ & $\begin{array}{r}0.015 \\
(0.019)\end{array}$ & $\begin{array}{r}0.065 \\
(0.199)\end{array}$ & $\begin{array}{r}0.067 \\
(0.038)\end{array}$ & $\begin{array}{r}-0.036 \\
(0.073)\end{array}$ \\
\hline$D(E(-1))$ & $\begin{array}{l}-7.858 \\
(4.559)\end{array}$ & $\begin{array}{r}0.737 \\
(0.551)\end{array}$ & $\begin{array}{r}0.048 \\
(0.107)\end{array}$ & $\begin{array}{r}1.395 \\
(1.119)\end{array}$ & $\begin{array}{r}0.280 \\
(0.216)\end{array}$ & $\begin{array}{r}0.715 \\
(0.410)\end{array}$ \\
\hline$D(E(-2))$ & $\begin{array}{r}2.860 \\
(5.117)\end{array}$ & $\begin{array}{l}-1.200 \\
(0.619)\end{array}$ & $\begin{array}{r}0.229 \\
(0.120)\end{array}$ & $\begin{array}{r}2.871 \\
(1.255)\end{array}$ & $\begin{array}{r}0.418 \\
(0.243)\end{array}$ & $\begin{array}{r}-0.134 \\
(0.460)\end{array}$ \\
\hline $\mathrm{D}(\mathrm{CPI}(-1))$ & $\begin{array}{r}3.186 \\
(2.698)\end{array}$ & $\begin{array}{l}-0.104 \\
(0.326)\end{array}$ & $\begin{array}{l}-0.038 \\
(0.063)\end{array}$ & $\begin{array}{l}-0.427 \\
(0.662)\end{array}$ & $\begin{array}{r}0.043 \\
(0.128)\end{array}$ & $\begin{array}{r}0.399 \\
(0.243)\end{array}$ \\
\hline $\mathrm{D}(\mathrm{CPI}(-2))$ & $\begin{array}{r}1.127 \\
(2.889)\end{array}$ & $\begin{array}{l}-0.341 \\
(0.349)\end{array}$ & $\begin{array}{r}0.017 \\
(0.068)\end{array}$ & $\begin{array}{l}-1.189 \\
(0.709)\end{array}$ & $\begin{array}{l}-0.167 \\
(0.137)\end{array}$ & $\begin{array}{r}-0.370 \\
(0.260)\end{array}$ \\
\hline C & $\begin{array}{r}6.138 \\
(10.771)\end{array}$ & $\begin{array}{r}2.143 \\
(1.303)\end{array}$ & $\begin{array}{l}-0.379 \\
(0.253)\end{array}$ & $\begin{array}{r}1.214 \\
(2.643)\end{array}$ & $\begin{array}{r}0.835 \\
(0.511)\end{array}$ & $\begin{array}{r}0.992 \\
(0.968)\end{array}$ \\
\hline R-squared & 0.70 & 0.35 & 0.62 & 0.92 & 0.53 & 0.48 \\
\hline $\begin{array}{l}\text { Adj. R-squared } \\
\text { Sum sq. resids }\end{array}$ & $\begin{array}{r}0.53 \\
11831.09\end{array}$ & $\begin{array}{r}-0.03 \\
173.10\end{array}$ & $\begin{array}{l}0.40 \\
6.52\end{array}$ & $\begin{array}{r}0.87 \\
712.23\end{array}$ & $\begin{array}{r}0.25 \\
26.60\end{array}$ & $\begin{array}{r}0.17 \\
95.62\end{array}$ \\
\hline S.E. equation & 23.19 & 2.80 & 0.54 & 5.69 & 1.10 & 2.08 \\
\hline F-statistic & 3.99 & 0.92 & 2.78 & 19.59 & 1.89 & 1.57 \\
\hline Log likelihood & -155.39 & -79.35 & -20.32 & -104.81 & -45.64 & -68.67 \\
\hline Akaike AIC & 9.41 & 5.19 & 1.91 & 6.60 & 3.31 & 4.59 \\
\hline Schwarz SC & 10.03 & 5.80 & 2.52 & 7.22 & 3.93 & 5.21 \\
\hline Mean dependent & 5.46 & 0.72 & -0.10 & 2.35 & 1.42 & 2.33 \\
\hline S.D. dependent & 33.68 & 2.76 & 0.70 & 16.00 & 1.27 & 2.29 \\
\hline \multicolumn{2}{|c|}{ Determinant resid covariance } & $2,088.23$ & & & & \\
\hline \multicolumn{2}{|l|}{ Log likelihood } & -444.08 & & & & \\
\hline \multicolumn{2}{|c|}{ Akaike information criterion } & 29.67 & & & & \\
\hline \multicolumn{2}{|c|}{ Schwarz criterion } & 33.63 & & & & \\
\hline
\end{tabular}

1/ Sample: 1996Q1-2004Q4; 36 observations; standard errors in parantheses. 


\section{References}

Bouhga-Hagbe, Jacques, 2004, “A Theory of Workers' Remittances with an Application to Morocco,” IMF Working Paper 04/194 (Washington: International Monetary Fund).

El-Sakka, Mohammed I., and Robert McNabb, 1999, “The Macroeconomic Determinants of Emigrant Remittances," World Development, Vol. 27, No. 8, pp. 1493-1502.

Giuliano, Paola, and Marta Ruiz-Arranz, 2005, "Remittances, Financial Development, and Growth,” IMF Working Paper 05/234 (Washington: International Monetary Fund).

Gupta, Poonam, 2005, “Macroeconomic Determinants of Remittances: Evidence from India,” IMF Working Paper 05/224 (Washington: International Monetary Fund).

International Monetary Fund, 2005, World Economic Outlook, April 2005 (Washington).

Johansen, Søren, 1991, "Estimation and Hypothesis Testing of Cointegration Vectors in Gaussian Vector Autoregressive Models," Econometrica, Vol. 59, No. 6, pp. 1551-1580.

Lucas, Robert E. B., and Oded Stark, 1985, "Motivations to Remit: Evidence from Botswana," Journal of Political Economy, Vol. 93, pp. 901-918.

Lueth, Erik, and Marta Ruiz-Arranz, 2006, “A Gravity Model of Workers' Remittances," IMF Working Paper (forthcoming) (Washington: International Monetary Fund).

Rajan, Raghuram; and Arvind Subramanian, 2005, "What Undermines Aid's Impact on Growth?,” IMF Working Paper 05/126 (Washington: International Monetary Fund).

Rapoport, Hillel, and Frédéric Docquier, 2005, “The Economics of Migrants' Remittances," IZA Discussion Paper 1531 (Bonn, Germany: Institute for the Study of Labor).

Ratha, Dilip, 2003, “Workers' Remittances: An Important and Stable Source of External Development Finance," Global Development Finance 2003, pp. 157-175 (Washington: World Bank).

Sayan, Serdar, 2006, "Business Cycles and Workers' Remittances: How Do Migrant Workers Respond to Cyclical Movements of GDP at Home?," IMF Working Paper 06/52 (Washington: International Monetary Fund).

Sri Lanka Bureau of Foreign Employment, 2004, Annual Statistical Report of Foreign Employment (Colombo).

Straubhaar, Thomas, 1986, “International Migrant Workers' Remittances: The Case of Turkey," Weltwirtschaftliches Archiv, Vol. 122, pp. 728-740. 